\title{
Empowering knowledge and Quality of Recovery after hip or knee replacement
}

\author{
Åsa Johansson Stark
}

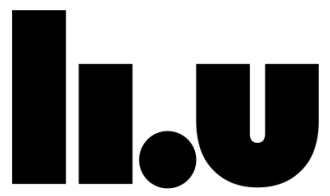

LINKÖPING UNIVERSITY

Division of Nursing Science

Department of Social and Welfare Studies

Faculty of Medicine and Health Sciences

Linköping University, Campus Norrköping, Sweden

Norrköping 2016 
(c) Åsa Johansson Stark 2016

Cover and illustrations by Åsa Johansson Stark

Photo by Eva Stark and Mats Johansson

Published articles have been reprinted with the permission of the copyright holder.

Printed in Sweden by LiU-Tryck, Linköping, Sweden, 2016

ISSN 0345-0082

ISBN 978-91-7685-876-9 


\title{
To my family
}

\author{
Mats, Hanna and Erik
}

Kunskapens rot är bitter men frukterna är söta. Aristoteles 384 f. $\mathrm{Kr}-322$ f.Kr. 


\section{Table of Contents}

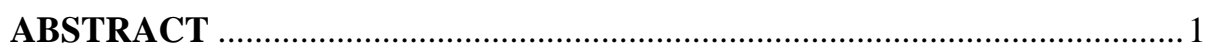

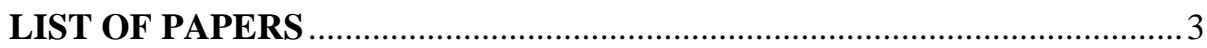

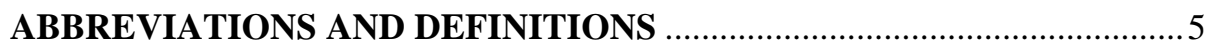

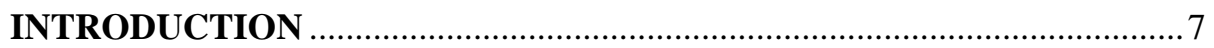

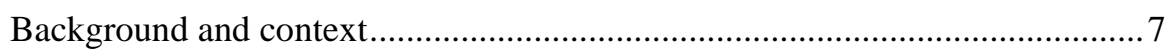

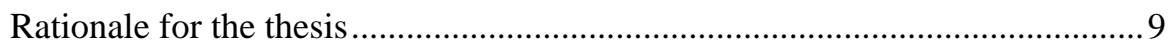

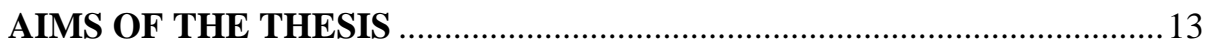

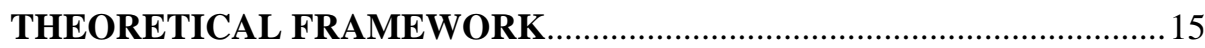

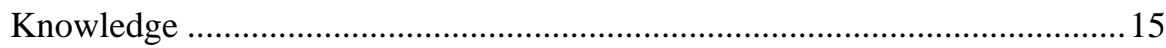

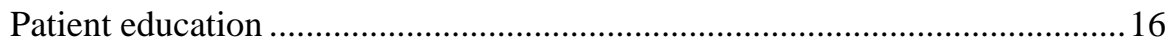

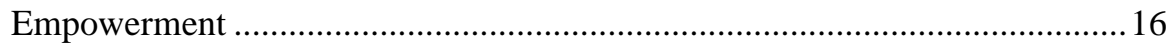

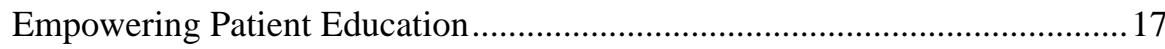

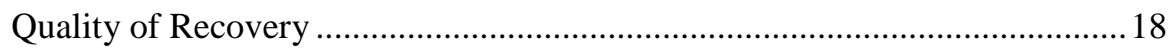

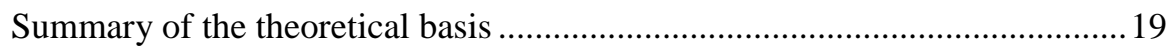

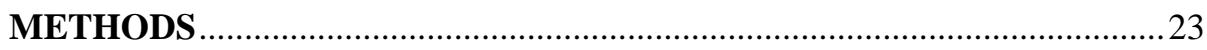

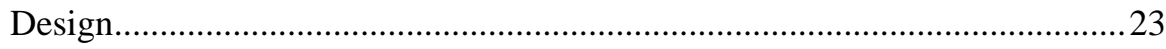

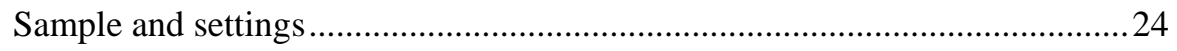

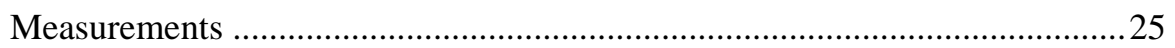

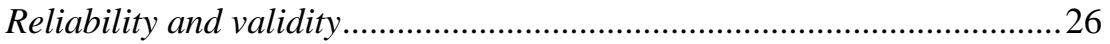

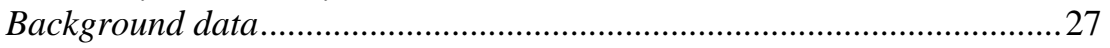

Fulfilment of knowledge expectations .......................................................2

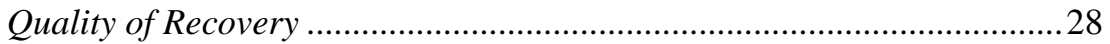

Access to knowledge ……......................................................................28

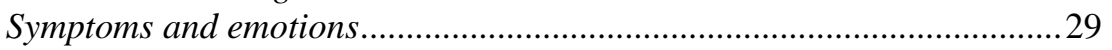

Patient satisfaction with care ....................................................................29

Preferences for information and behavioural control..............................29

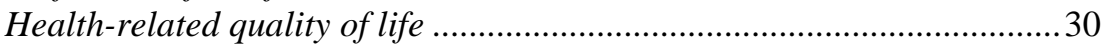




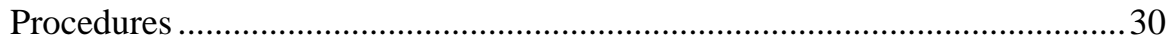

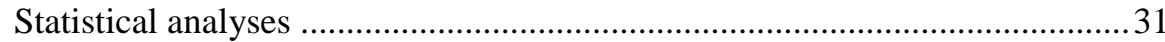

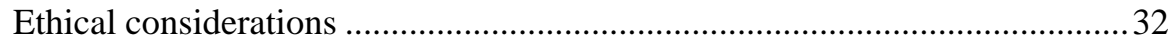

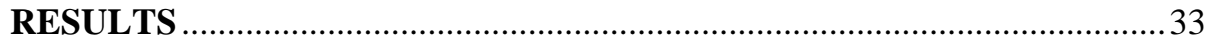

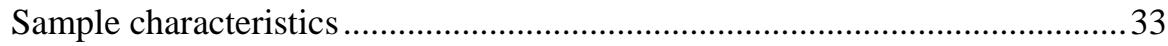

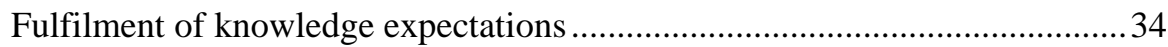

Background factors related to fulfilment of knowledge expectations ........36

Factors associated with fulfilment of knowledge expectations ...................37

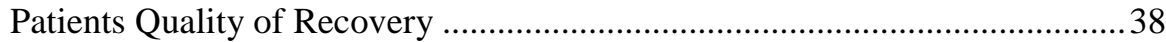

Variables predicting the Quality of Recovery ............................................40

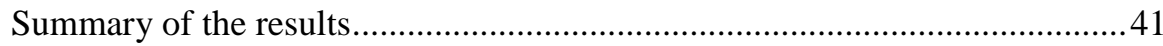

DISCUSSION

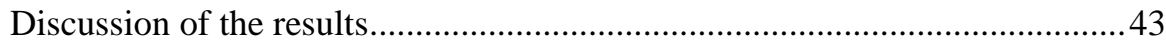

Empowering knowledge ……………....................................................4

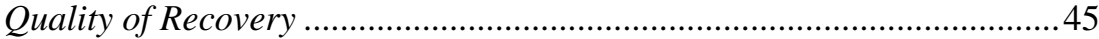

Improving patients Quality of Recovery ..................................................48

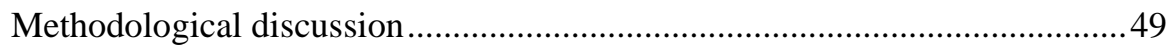

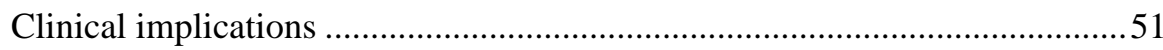

Recommendations for further research ......................................................52

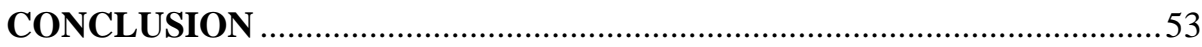

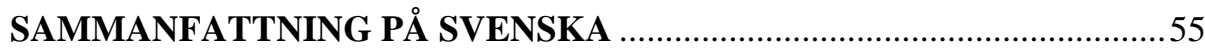

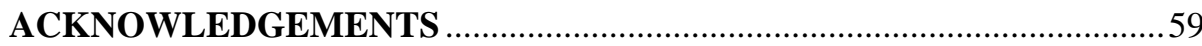

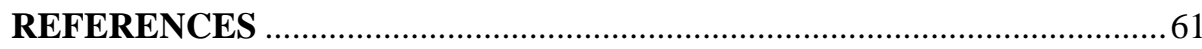

Paper I

Paper II

Paper III

Paper IV 


\section{Abstract}

\section{Background}

Arthroplasty is commonly used for an increasing population of patients with osteoarthritis, and the recovery process starts directly after surgery. Today's shorter hospital stay may be a challenge for the patients and their spouses. Patient education is linked to and promotes the recovery process and can improve the outcome after elective hip or knee replacement. Fulfilment of knowledge expectations is essential for enabling people to become empowered during the period of recovery.

\section{Aim}

The overall aim was to explore the association between empowering knowledge and patients' quality of recovery after elective hip or knee replacement.

\section{Methods}

The design of the four papers was descriptive, prospective and comparative. Consecutively included patients and their spouses from Cyprus, Finland, Greece, Iceland and Sweden answered questionnaires before surgery and at discharge from hospital. Data was collected during the years 2009-2012. Relationships and associations between a number of factors and fulfilment of knowledge expectations, and patients' quality of recovery were investigated. Comparisons between patients undergoing hip or knee replacement and between patients and their spouses were made.

\section{Results}

Patients and their spouses had similar knowledge expectations, and these were not fulfilled during the hospital stay. Spouses had less fulfilled knowledge expectations compared with the patients. Swedish patients and spouses had less fulfilled knowledge expectations compared with the Icelandic and Finnish ones. Patients who experienced the hospital stay as meeting their general expectations had more fulfilled knowledge expectations compared with those who did not.

Access to knowledge was the main predictor of the variance in fulfilment of knowledge expectations. Negative emotions, such as depressive state and impatience, were associated with less fulfilled knowledge expectations. For patients 
undergoing hip replacement, a higher level of professional education was associated with less fulfilled knowledge expectations. For patients undergoing knee replacement, a history of employment in social services or healthcare was associated with less fulfilled knowledge expectations.

Patients' experience of greater satisfaction with care was associated with better quality of recovery for both kinds of arthroplasty. Patients with fulfilled knowledge expectations experienced better quality of recovery. The spouserelated factors, namely uncertainty and depressive state, were associated with lower quality of recovery. Factors associated with greater quality of recovery among the patients were spouses with a history of employment in social services or health care, and nurses explaining matters concerning the care and treatment for the spouses.

\section{Conclusion}

Patients and their spouses had high knowledge expectations that were not fulfilled during the hospital stay. Patients' emotional state and their access to knowledge were important for their fulfilment of knowledge expectations. Patients' and spouses' emotional state also played an important role in determining the patients' quality of recovery, and greater satisfaction with care among the patients was associated with better quality of recovery.

These results emphasise the need to detect patients and their spouses in need of support in their preparation and recovery process. It is therefore important to assess patients' and spouses' personal knowledge expectations, and adapt to their emotional state while fulfilling them.

The content of patient education should be personalised in future care, and informal caregivers should be seriously taken into account during the period of early recovery. The results of this thesis can be used in the development and testing of person-centred educational interventions for patients undergoing elective hip or knee replacements. 


\section{List of papers}

This thesis is based on the following four papers, which will be referred to by their Roman numerals:

I. Johansson Stark Å, Ingadottir B, Salanterä S, Sigurdardottir A, Valkeapää K, Bachrach-Lindstrom M, Unosson M (2014): Fulfilment of knowledge expectations and emotional state among people undergoing hip replacement: A multi-national survey. International Journal of Nursing Studies 51, 1491-1499.

II. Ingadottir B, Johansson Stark Å, Leino-Kilpi H, Sigurdardottir AK, Valkeapää K, Unosson M (2014): The fulfilment of knowledge expectations during the perioperative period of patients undergoing knee arthroplasty - a Nordic perspective. Journal of Clinical Nursing 23, 2896-2908.

III. Johansson Stark ^, Charalambous A, Istomina N, Salanterä S, Sigurdardottir A, Sourtzi P, Valkeapää K, Zabalegui A, BachrachLindström M: The Quality of recovery on discharge from hospital, a comparison between patients undergoing hip and knee replacement - a European study. Resubmitted to Journal of Clinical Nursing.

IV. Johansson Stark, ̊, Salanterä S, Sigurdardottir A, Valkeapää K, Bachrach-Lindström M: Spouse-related factors associated with Quality of recovery of patients after hip or knee replacement - a Nordic perspective. Submitted to International Journal of Orthopaedic and Trauma Nursing. 



\title{
Abbreviations and definitions
}

\author{
Abbreviations: \\ AKS Access to Knowledge Scale \\ EPE Empowering Patient Education \\ EQ-5D EuroQoL 5-dimensions, measuring health status (HRQoL) \\ HRQoL Health-Related Quality of Life \\ $\mathrm{KE}_{\mathrm{hp}} \quad$ Knowledge Expectations, hospital patients \\ $\mathrm{KE}_{\mathrm{so}} \quad$ Knowledge Expectations, significant others \\ KHOS Krantz Health Opinion Survey \\ PSS Patient Satisfaction Scale \\ $\mathrm{RK}_{\mathrm{hp}} \quad$ Received Knowledge, hospital patients \\ $\mathrm{RK}_{\mathrm{so}} \quad$ Received Knowledge, significant others \\ QoR Quality of Recovery
}




\section{Definitions:}

Empowering knowledge

Fulfilled knowledge expectations

Unfulfilled knowledge expectations

Quality of Recovery

Spouse
The difference between received and expected knowledge, i.e. fulfilment of knowledge expectations. Empowering knowledge enables people to become empowered concerning their own health (Leino-Kilpi et al. 1999).

No or a positive difference between received and expected knowledge.

A negative difference between received and expected knowledge.

Is defined from a self-perceived perspective using five dimensions of health; comfort, emotions, physical independence, patient support, and pain (Gornall et al. 2013, Myles et al. 2000).

Wife, husband, cohabiting partner 


\section{Introduction}

The focus of this thesis is on patients and their spouses' perceptions of empowering knowledge, and its associations with patients' quality of recovery after elective hip or knee replacement. Data used in the papers were collected using questionnaires distributed in five European countries: Cyprus, Finland, Greece, Iceland, and Sweden.

The thesis is a part of the European research project 'Empowering Surgical Orthopaedic Patients through Education'. The project includes collaboration between researchers in healthcare and nursing science in seven countries: Cyprus, Finland (project leader), Greece, Iceland, Lithuania, Spain and Sweden (EEPO 2009). Publications from the European project are marked with an asterisk $(*)$ in the reference list. Empowering Patient Education (EPE) was studied in a Finnish context before the European project started. This thesis expands the understanding of empowering knowledge and its relationships with quality of recovery (QoR) in a Nordic, and European context.

\section{Background and context}

Patient education is linked to and promotes the recovery process and can improve the outcome after hip or knee replacement (Murphy et al. 2011, Tay Swee Cheng et al. 2015). The procedure of elective hip or knee replacement starts with the medical decision regarding the need for surgical treatment and then continues from admission to hospital to the recovery period in the patients' home.

Osteoarthritis is a common musculoskeletal disease in middle-aged and older people which causes pain and loss of physical functioning (Gandhi et al. 2015, Gooberman-Hill et al. 2009). Worldwide estimates are that $18 \%$ of women and 10\% of men aged over 60 have symptomatic osteoarthritis (WHO 2012). Even though exercise can provide benefits, such as reduced pain and improved physical function (Fransen et al. 2015), hip and knee replacements are successful treatments for the increasing population of persons with osteoarthritis.

Hip and knee replacements constitute a large proportion of arthroplasty operations performed throughout Europe. The incidence rates per 100,000 inhabitants were 157 for patients undergoing hip replacement and 113 for patients undergoing knee replacement in the OECD (Organisation for Economic Cooperation and Development) countries during 2012. Variations in hip and knee replacement rates in the OECD countries, and between hospitals and regions in 
the same country may be due to differences in the healthcare system, different indication criteria, or the population age structure. The Nordic countries of Finland, Iceland and Sweden had similar annual incidence rates, which were above the average for the OECD countries. The incidence rates were below the average for the OECD countries in Greece and Cyprus, and therefore lower compared with the Nordic countries (OECD 2014).

The recovery process starts directly after surgery and improvements occur during the whole recovery period, even after several years (Browne et al. 2013). It takes several weeks for elderly patients with severe osteoarthritis to recover after hip or knee replacement (Hamel et al. 2008). The process of recovery after hip replacement has been found to be similar for patients who recover quickly and those who have a more problematic recovery (Grant et al. 2009). This recovery process has been experienced by older adults as three interrelated processes: reclaiming physical ability, re-establishing roles and relationships, and refocusing the self. These three processes include physical, psychological, and social recovery (Grant et al. 2009). The papers in the thesis focus on the early period of postoperative recovery, and the QoR is described from a personal, selfperceived and multidimensional perspective, at the time of discharge from hospital (Gornall et al. 2013).

The Nordic countries have similar public healthcare systems (Lohmander et al. 2006). Greece has a national public healthcare system, while Cyprus has comparably sized systems of public and private healthcare (Economou 2010, Theodorou 2012, WHO/Europe 2015). When the welfare systems were created in Finland, Iceland and Sweden, responsibilities previously assumed by the family were taken over by the state. This legislation has made the Nordic countries the least family-dependent and most individualised societies in the world. The family is a central social institution in the Nordic countries, but the moral logic of the society emphasises autonomy and equality (Berggren et al. 2011, Johansson et al. 2011). Southern Europe, including for example Cyprus and Greece has more traditional family values, e.g. greater family involvement during hospital stays, compared with the Nordic countries (Cultural map, 2010-2014). Spousal caregivers are considered to be primary caregivers as their relationship with the patient are more interdependent than other family caregivers (Baucom et al. 2012, Lewis et al. 2006, Meyler et al. 2007). In the Nordic context, which emphasises autonomy and equality within the family, spouses are the most common family caregivers.

However, reductions in institutional care and cutbacks in public services have had, more or less, negative consequences for patients in many European countries (EGGE 2012). This policy to reduce costs, but also medical advances and new approaches to care, have resulted in shorter hospital stays after hip and 
knee replacements, from 15 days during the 80s to 4-6 days today (Anastase et al. 2014, Mäkelä et al. 2014, Sundberg et al. 2014). With today's shorter hospital stays the patients need to take more responsibility for their own recovery. Qualitative studies have concluded that persons undergoing orthopaedic surgery perceive many limitation such as loss of independence, and limitations in function and activity. Early discharge from hospital seems to cause even more problems during the recovery period (Perry et al. 2012, Reay et al. 2015). Therefore spouses play an important role during the recovery process. Increased age of patients and their spouses is another reason why the recovery period in their home environment may be problematic to them. It is therefore important for nurses to collaborate with patients and their spouses as a care unit. A short hospital stay also means that nurses meet patients during the early phase of recovery and they therefore may have limited experience regarding the late phase of postoperative recovery (Allvin et al. 2008). Including patients and their spouses in the care may therefore be an important challenge for the nurses. In structured person-centred admission and discharge planning, patients' resources and social situation are identified. This means that spouses are included in the patients' narrative and become a part of the shared health plan (Ulin et al. 2015). This collaboration with spouses as informal caregivers facilitates safe return to home when patients need support during the postoperative recovery process. Person-centred care has also been shown to result in a shorter hospital stay compared with conventional care for patients undergoing elective hip replacement (Olsson et al. 2014).

\section{Rationale for the thesis}

For an increasing population of persons with osteoarthritis, hip and knee replacements are successful treatments. The intentions of this thesis correspond to the European commission's actions for chronic diseases, namely to promote citizen and patient empowerment, and support patients in managing their own disease (EU 2014).

In a Finnish study with the aim of exploring orthopaedic nurses' perceptions of patient education, using the theoretical basis of EPE, no positive changes were found regarding patient education during the past decade (Eloranta et al. 2015). This highlights the need to improve EPE in connection with elective hip or knee replacement. Studies using the theoretical basis of EPE have been conducted in a Finnish context on medical and surgical patients (Heikkinen et al. 2007, LeinoKilpi et al. 1998, Rankinen et al. 2007, Rantanen et al. 2008). However, this field of research is now in a phase of expansion to a European context (Klemetti et al. 2014, Koekenbier et al. 2015, Vaartio-Rajalin et al. 2014, Valkeapää et al. 2014). 
In the strategic goals of the European Patient Forum, empowerment, along with access to information and education, have recently been highlighted as factors that enable patients and informal caregivers to make informed choices (EPF 2013). There are also valid and reliable instruments to measure empowering knowledge, even though further validation is needed in the European context. This thesis expands the research field by including patients from Cyprus, Finland, Greece, Iceland and Sweden, and spouses from Finland, Iceland and Sweden.

In many countries, education is provided to prepare patients for surgery, discharge and postoperative recovery but patient education still needs to be further developed, especially in hospital care (Bergh et al. 2012, Friberg et al. 2012). With more fast track treatment followed by early discharge it is vital to improve patient education. Patient education which focuses on supporting the empowerment of patients by providing them with the knowledge they expect is therefore important. To generate knowledge that can support the development of EPE, international studies are essential.

Empowering knowledge emphasises the capacity and knowledge of the patients. The assumption is that if persons have their knowledge expectations fulfilled they will have the possibility to become empowered in regard to their own health (Leino-Kilpi et al. 2005a). Results from earlier studies show that patients expect a wide range of knowledge, and those expectations are not adequately met during the hospital stay (Heikkinen et al. 2007, Rankinen et al. 2007, Ryhanen et al. 2012). There is limited knowledge about whether patients undergoing hip or knee replacement have their knowledge expectations fulfilled during hospital stays. To support patients' empowerment through education there is therefore a need to be aware of these expectations and the factors that influence them. Patients undergoing different kinds of arthroplasty may also have different knowledge expectations; therefore a comparison between the two kinds of arthroplasty seems important. If patients lack empowering knowledge, it might affect their postoperative recovery process. Spouses may also lack empowering knowledge, and may therefore not be able to experience empowerment during their partners' recovery process, in which they play an important role due to today's short hospital stays.

Emotional state may affect the extent to which knowledge expectations are fulfilled. In qualitative studies exploring experiences of orthopaedic surgery, patients' emotions such as hope, fear, feeling safe and loss of independence seem to be more important than their symptoms (Gustafsson et al. 2010, Perry et al. 2012, Soever et al. 2010). No studies have been found describing how patients or their spouses' emotions are related to empowering knowledge; this is therefore important to study. It is known that emotional support from spouses can improve 
patients' recovery outcomes after knee replacement, for example by strengthening the patient's belief in being able to manage his/her own recovery, and providing positive emotional responses to improve the patients' recovery (Khan et al. 2009, Stephens et al. 2009). Due to the interdependence between the patients and their spouses it is of clinical interest to analyse the relationships between characteristics and other background factors, such as the emotional state of spouses, and patients' QoR.

Patient education is closely linked to the recovery process and promotes early recovery (Murphy et al. 2011, Tay Swee Cheng et al. 2015). It is therefore relevant to study the relationship between empowering knowledge and QoR during the early period of recovery; in addition, this relation has not been studied before. With today's ever shorter hospital stays the patients need to be more responsible for their own recovery. Spouses also play an important role in the early recovery process due to today's short hospital stays and the increased age of patients (OECD 2014). This can be problematic, and the patients and their spouses may need support in handling challenges during the period of recovery. To be able to identify patients at risk of poor QoR, it is important to identify factors that are related to QoR. Earlier studies show that patients undergoing hip replacement improve better in postoperative function compared with those undergoing knee replacements (Choi et al. 2012, de Beer et al. 2012, O'Brien et al. 2009). Therefore, a comparison of QoR of patients having those two kinds of arthroplasty seems important.

In a Nordic and European context little is known about factors associated with empowering knowledge after hip or knee replacement. There is also a lack of knowledge of the factors involved in successful postoperative recovery. If background factors associated with empowering knowledge and patients QoR can be identified, it may help nurses to identify patients and their spouses in need of support during the period of hospitalisation. 



\section{Aims of the thesis}

The overall aim of this thesis was:

to explore the association between empowering knowledge and patients' quality of recovery after elective hip or knee replacement.

\section{The specific aims were as follows:}

\section{Paper I}

To describe the differences between received and expected knowledge in patients undergoing elective hip replacement in three Nordic countries, and to analyse how these differences are related to patients' characteristics, preoperative symptoms and emotions.

\section{Paper II}

To describe the possible differences between knowledge expectations and received knowledge of patients undergoing elective knee arthroplasty in Iceland, Sweden and Finland and also to determine the relationship between such a difference and both background factors and patient satisfaction with care.

\section{Paper III}

To describe and compare the quality of recovery on discharge from hospital between patients undergoing elective hip or knee replacement. The study will also attempt to identify any predicting factors.

\section{Paper IV}

To describe spouse-related factors that were associated with patients' quality of recovery on discharge from hospital after hip or knee replacement. 



\section{Theoretical framework}

To be able to improve patients' quality of recovery after elective hip or knee replacement, healthcare professionals need to detect the patients, and also their spouses, in need of early support in their preparation and recovery process. It is therefore important to identify background factors related to empowering knowledge and patients' quality of recovery for each kind of arthroplasty. The assumptions regarding the relationships between background factors, empowering knowledge and QoR in this thesis are presented in figure 1, page 20.

\section{Knowledge}

There is no sharp dividing line between science and philosophy. Philosophy deals with framework questions and other questions that we do not know how to answer systematically. The question 'Do patients have their knowledge expectations fulfilled?' is a scientific question while 'What is the nature of knowledge?' is a philosophical question. To find a definition of knowledge, scientific knowledge and knowledge in general, the work of Aristotle is still valid. Aristotle believed that knowledge was based on perceptions, and he classified it into three different types; episteme (scientific), techne (skill and crafts) and phronesis (wisdom) (Searle 1999). This classification is widely used today, and empowering knowledge can be understood from these three types of knowledge. For example, patients can have scientific/theoretical knowledge about their postoperative pain, experiencing the skills to take functional control of the situation caused by the pain, and have the perception of being a unique and respected person while acting to control their pain. Empowering knowledge is also multidimensional consisting of six dimensions of knowledge; biophysiological, functional, experiential, social ethical and financial (Leino-Kilpi $e t$ al. 2005b). Thus, knowledge is multidimensional and should be interpreted in the papers of this thesis from the patients or their spouses' perceptions of empowering knowledge, taking the three types of knowledge into account. Neither knowledge nor empowerment can be given to a person; they can only be experienced, in this case, by patients and their spouses. This means that all parts of the thesis should be interpreted from the patients' or their spouses' perspective. 


\section{Patient education}

Patient education, provided by healthcare professionals, has developed in Europe and North America, from healthcare professionals deciding what the patient needed to know, to shared decision-making with equal influence on the decision making process (Hoving et al. 2010). It is a planned educational activity designed to improve patients' knowledge and/or health behaviour. Patient education has been defined in Europe as educational activities directed towards patients, including aspects of therapeutic education, health education and clinical health promotion (Visser et al. 2001). Person-centred education is respectful and individualised; patients and their spouses should be empowered to be involved in health decisions, at whatever level they desire (Morgan \& Yoder 2012).

Patient education is one element of the 'Code of Ethics for Nurses'. It states that the nurse should ensure that the individual receives accurate, sufficient and timely information in a culturally appropriate manner (ICN 2012). A review has shown that many nurses regarded patient education as a significant part of everyday practice, but also that patient education was not considered as a part of routine care (Friberg et al. 2012). Even though nurses may have different views on the importance of patient education, the patient's right to information is uncontested. In some countries, this right is even statutory, such as in Finland (Act 785/1992), Greece (Act GR-2071/92, \& 2619/98), Iceland (Act 74/1997), and Sweden (Act 1982:763). The pedagogical process consists of setting learning objectives, the use of different educational methods, and evaluation of learning outcomes, and should therefore be implemented in the nursing process (Eloranta et al. 2015).

In this thesis, patient education is seen as an empowering educational activity. The focus is on empowering knowledge, as it is perceived by the patients and their spouses. It is not an evaluation of existing patient education, as the information and education were delivered according to standard procedures at each hospital.

\section{Empowerment}

The concept of empowerment has been adopted within healthcare. It is an abstract concept, frequently used in the literature. The concept has been defined in a variety of manners; it has its roots in social, organisational, and psychological theories (Aujoulat et al. 2008, Bradbury-Jones et al. 2008, Gibson 1991, Kuokkanen \& Leino-Kilpi 2000, Oudshoorn 2005).

Empowerment is a level of experiencing power in one's own life which is a basis for health. A review has recently identified three interpretations of patient 
empowerment; first, as a state of 'being empowered' that allows patients to have an active role in their own care; second, as 'the process of empowering patients', leading to patients' achievement of being empowered; third, as 'empowered behaviours' through which patients participate in self-management and shared decision-making. Most of the studies in the review defined empowerment as a combination of ability, motivation and power opportunities (Fumagalli et al. 2015).

Another review used the three theoretical approaches suggested by Kuokkanen and Leino-Kilpi (2000): organisational/structural theories, psychological theories, critical social theory of empowerment, and in addition, mixed theoretical approaches. Studies using EPE as the theoretical framework were considered to be based on the psychological theories. These studies emphasised the individual perspective of nurses' empowerment (Kennedy et al. 2015), which is also the case in the papers of this thesis, but from the patients' and their spouses' individual perspectives.

Thus, the background of empowerment in this thesis lies mainly in socialpsychological theories and constructive learning theory, and has been developed for healthcare purposes (Leino-Kilpi et al. 1998, Leino-Kilpi et al. 1999). The emphasis is on the individual nature of empowerment which can be seen as a process as well as an outcome (Aujoulat et al. 2008, Gibson 1991, Rappaport 1984). The process involves learning, whereby a person reconstructs his/her ways of thinking and acting to achieve empowerment. As an outcome, it is a state of being empowered and having an active role in one's own care, or experiencing power in one's own life (Fumagalli et al. 2015).

\section{Empowering Patient Education}

The theoretical basis of EPE emphasises the individual's capacity, and patients' rights to know about their health, health-related problems, treatment and care. Empowered patients have the ability to recognise the limitations of knowledge, and they are able to understand knowledge, to make decisions and solve problems and take actions concerning their own health and treatment. It is essential to be aware of patients' knowledge expectations and their perceptions of received knowledge. The basic assumption is that if patients have their knowledge expectations fulfilled they will have the possibility to become empowered concerning their own health. It is also assumed that spouses with fulfilled knowledge expectations have the possibility to become empowered during the period of recovery, when the patients may need support from them (Heikkinen et al. 2007, Leino-Kilpi et al. 1999, Rankinen et al. 2007, Sigurdardottir et al. 2015). 
EPE involves six dimensions of knowledge that patients may need to manage their health problems:

bio-physiological the patient knows the physiological signs and symptoms, has sufficient knowledge of them, and feels that he/she can control problems caused by the symptoms,

functional the patient is able to take functional control of the situation, feels that he/she has the strength to do so, and is able to act in the manner he/she wishes in order to remove or control the health problem,

experiential the patient is able to use previous experiences to help control the health problem,

social

the patient feels that he/she can remain a member of the social community despite the health problem, and that the care environment and the social contacts it includes support control of the health problem,

ethical

the patient experiences him/herself as a unique, respected individual, and feels that the motive behind the care he/she is receiving is for his/her well-being,

financial the patient is able to get by financially with his/her health problem, and the care is performed in a manner that financially burdens him/her the least (Leino-Kilpi et al. 2005b, Rankinen et al. 2007).

These aspects of empowering knowledge are all important, as patients need to be prepared for both the surgical procedure and the postoperative recovery process.

When patient education results in empowering knowledge, healthcare professionals support patients in their empowering process. EPE meets the patients' needs by providing advice and guidance and taking patients' level of knowledge, abilities, attitudes and values into account (Virtanen et al. 2007).

\section{Quality of Recovery}

The concept of recovery began to develop within psychiatric rehabilitation during the late 1980s. The concept has recently been redefined within this field as a process including a meaningful life with full participation in activities and social roles. Shared decision making as well as patient education are ways to improve the patients' opportunities to live the kind of life they associate with 
recovery (Whitley 2014). Recovery models within psychiatric care emphasise empowerment and the person's own experiences of health (Slade \& Longden 2015). This emphasis on empowerment and the person's own experiences can also be applied within postoperative care after hip or knee replacement. The most common distinction of recovery in psychiatric care is that made between personal and clinical recovery (Macpherson et al. 2015). Another distinction, between the personal and social approach to recovery has also been made (Vandekinderen et al. 2012). This division is supported by a qualitative study where it was shown that the recovery process after hip replacement could lead to changes in personal and social functioning that patients did not always anticipate (Grant et al. 2009).

The concept of postoperative QoR is commonly used but it lacks a universally accepted definition. Traditionally, QoR has focused on clinically physiological outcomes, but nowadays the focus has changed to multidimensional postoperative function and patient-focused outcomes (Bowyer et al. 2014). A concept analysis suggests that postoperative recovery can be defined as an energy-requiring process until the preoperative level of normality and wholeness regarding physical, psychological, social and habitual functions has been restored (Allvin et al. 2007). This definition corresponds with the view of this thesis. In the papers QoR is described from a personal, self-perceived perspective, and is measured by using five dimensions of health; comfort, emotions, physical independence, patient support, and pain (Gornall et al. 2013, Myles et al. 2000). This means that QoR is defined from a subjective, multidimensional perspective.

The process of recovery after hip or knee replacement starts directly after surgery, and it takes several weeks or even years to recover to the level that each individual perceives as normality (Browne et al. 2013, Hamel et al. 2008). Postoperative recovery frequently refers to recovery from anaesthesia (Grover \& Haire 2004, Parida \& Badhe 2014). This is not the case after hip or knee replacement when the recovery process refers to patients' perceptions of the outcomes of the surgery (Perry et al. 2012). Patients' perceptions of their health prior to surgery are therefore important for their perceptions of normality after recovery. In the papers of this thesis, early recovery refers to the time of discharge from hospital.

\section{Summary of the theoretical basis}

Most of the dimensions of the definition of postoperative recovery by Allvin et al. (2007) correspond with the dimensions of empowering knowledge. Both views are multidimensional and based on patients' perceptions. If patients are provided with knowledge covering for example the bio-physiological and social 
dimensions of knowledge (Leino-Kilpi et al. 1999), it is possible that the recovery as regards physical and social functions will be supported (Allvin et al. 2007). The multidimensional measurements of quality of recovery in the papers of this thesis includes five dimensions of health (Myles et al. 2000) which are also covered by the content of empowering knowledge, and therefore might be supported by EPE.

The theoretical basis of this thesis is based on the concepts presented in figure 1. The figure is developed from the theoretical basis of the European project described in Klemetti et al. (2014). Empowering knowledge is used to describe essential knowledge which patients and their spouses need to support their empowerment. Empowering knowledge is the difference between received and expected knowledge, also described as fulfilment of knowledge expectations.

\begin{tabular}{|c|c|c|c|}
\hline Background factors & Empowering & Background factors & QoR \\
\hline $\begin{array}{c}\text { For example: } \\
\text { DEMOGRAPHICS } \\
\text { - Age } \\
\text { - Sex } \\
\text { - Level of education } \\
\text { CLINICAL FACTORS } \\
\text { - Hip or knee } \\
\text { replacement } \\
\text { - First or previous } \\
\text { experience of } \\
\text { arthroplasty } \\
\text { PERSONAL FACTORS } \\
\text { - Emotional state } \\
\text { - History of employment } \\
\text { in social service or } \\
\text { healthcare } \\
\text { - Hospital stay as } \\
\text { expected } \\
\text { KNOWLEDGE } \\
\text { - Access to knowledge } \\
\text { COUNTRY } \\
\text { Cyprus, Finland, Iceland, } \\
\text { Spain, Sweden }\end{array}$ & $\begin{array}{l}\text { DIFFERENCES } \\
\text { BETWEEN } \\
\text { RECEIVED AND } \\
\text { EXPECTED } \\
\text { KNOWLEDGE }\end{array}$ & $\begin{array}{c}\text { For example: } \\
\text { DEMOGRAPHICS } \\
\text { - Age } \\
\text { - Sex } \\
\text { - Level of education } \\
\text { CLINICAL FACTORS } \\
\text { - Hip or knee } \\
\text { replacement } \\
\text { - Length of hospital } \\
\text { stay } \\
\text { PERSONAL FACTORS } \\
\text { - Emotional state } \\
\text { - History of } \\
\text { employment in social } \\
\text { service or healthcare } \\
\text { - Satisfaction with care } \\
\text { - Support from spouses } \\
\text { KNOWLEDGE } \\
\text { - Access to knowledge } \\
\text { - Empowering } \\
\text { knowledge } \\
\text { counTRY } \\
\text { - Cyprus, Finland, } \\
\text { Iceland, Spain, Sweden }\end{array}$ & $\begin{array}{l}\text { Patients' } \\
\text { Quality of } \\
\text { Recovery }\end{array}$ \\
\hline
\end{tabular}

Figure 1. Overview of the relationships between background factors, empowering knowledge and Quality of Recovery in the thesis 
The assumption is that patients' or spouses' background factors can be related to empowering knowledge. Another assumption is that empowering knowledge, together with other background factors, such as the characteristics and emotional state of the patients and their spouses, can be related to the patients' quality of recovery. Support from spouses might also be a background factor related to patients' QoR. 



\section{Methods}

\section{Design}

The design of the four multi-centre, cross-cultural papers was descriptive, prospective and comparative. Patients and their spouses answered questionnaires before surgery and at discharge from hospital after elective hip or knee replacement.

Table 1. Design, participants and data analysis in papers I, II, III and IV

\begin{tabular}{|c|c|c|c|}
\hline Design & Participants & Country & Data analysis* \\
\hline $\begin{array}{l}\text { Paper I } \\
\text { Descriptive } \\
\text { Prospective }\end{array}$ & $\begin{array}{l}320 \text { Patients } \\
\text { Hip replacement } \\
\text { mean age: } 64( \pm 11) \\
\text { female: } 55 \%\end{array}$ & $\begin{array}{l}\text { Finland } 97(30 \%) \\
\text { Iceland } 98(31 \%) \\
\text { Sweden } 125(39 \%)\end{array}$ & $\begin{array}{l}\text { Descriptive statistics, } \\
\text { Reliability tests, } \\
\text { Inferential statistics, } \\
\text { Multiple stepwise } \\
\text { regression }\end{array}$ \\
\hline $\begin{array}{l}\text { Paper II } \\
\text { Descriptive } \\
\text { Prospective }\end{array}$ & $\begin{array}{l}290 \text { Patients } \\
\text { Knee replacement } \\
\text { mean age: } 67( \pm 9) \\
\text { female: } 52 \%\end{array}$ & $\begin{array}{l}\text { Finland } 80(28 \%) \\
\text { Iceland } 109(38 \%) \\
\text { Sweden } 101(35 \%)\end{array}$ & $\begin{array}{l}\text { Descriptive statistics, } \\
\text { Reliability tests, } \\
\text { Inferential statistics, } \\
\text { Multiple stepwise } \\
\text { regression }\end{array}$ \\
\hline $\begin{array}{l}\text { Paper III } \\
\text { Descriptive } \\
\text { Prospective } \\
\text { Comparative }\end{array}$ & $\begin{array}{l}865 \text { Patients } \\
413 \text { (48\%) Hip } \\
\text { mean age: } 65( \pm 12) \\
\text { female: } 53 \% \\
452(52 \%) \text { Knee } \\
\text { mean age: } 67( \pm 9) \\
\text { female: } 61 \%\end{array}$ & $\begin{array}{l}\text { Cyprus } 145(17 \%) \\
\text { Finland } 150(17 \%) \\
\text { Greece } 175(20 \%) \\
\text { Iceland } 187(22 \%) \\
\text { Sweden } 208(24 \%)\end{array}$ & $\begin{array}{l}\text { Descriptive statistics, } \\
\text { Reliability tests, } \\
\text { Inferential statistics, } \\
\text { Linear regression, in } \\
\text { two steps, } \\
\text { Multicollinearity }\end{array}$ \\
\hline $\begin{array}{l}\text { Paper IV } \\
\text { Descriptive } \\
\text { Prospective } \\
\text { Comparative }\end{array}$ & $\begin{array}{l}306 \text { Spouses } \\
\text { mean age: } 64( \pm 10) \\
\text { female: } 54 \% \\
\text { Patients } \\
152(50 \%) \text { Hip } \\
151(50 \%) \text { Knee } \\
\text { mean age: } 65( \pm 9) \\
\text { female: } 45 \%\end{array}$ & $\begin{array}{l}\text { Finland } 74(24 \%) \\
\text { Iceland } 94(31 \%) \\
\text { Sweden } 138(45 \%)\end{array}$ & $\begin{array}{l}\text { Descriptive statistics, } \\
\text { Reliability tests, } \\
\text { Inferential statistics, } \\
\text { Multiple stepwise } \\
\text { regression, } \\
\text { Multicollinearity }\end{array}$ \\
\hline
\end{tabular}

*Statistical analyses are described more in detail on page 31 


\section{Sample and settings}

The sample consisted of consecutively included patients with osteoarthritis on waiting lists for elective hip or knee replacement, and their spouses in the Nordic countries of Finland, Iceland and Sweden, and patients from the southern European countries of Cyprus and Greece. The settings were university or community hospitals; two in Cyprus, two in Finland, three in Greece, three in Iceland, and two in Sweden. In Cyprus and Iceland all hospitals performing arthroplasty were included; the other hospitals were non-randomly selected.

Inclusion criteria for the patients were: undergoing elective hip or knee replacement with the ICD-codes: M16-M16.9, M17-M17.9 (M=osteoarthrosis 16=hip, 17=knee), 18 years or older, able to complete questionnaires independently or with help from family members, and able to understand Finnish, Greek, Icelandic or Swedish. The exclusion criterion was having a diagnosed cognitive disorder.

The Nordic countries of Finland, Iceland and Sweden were included in papers I, II and IV, while Cyprus, Finland, Greece, Iceland and Sweden were included in paper III. The main sample for the different papers was the same and is described in figure 2 .

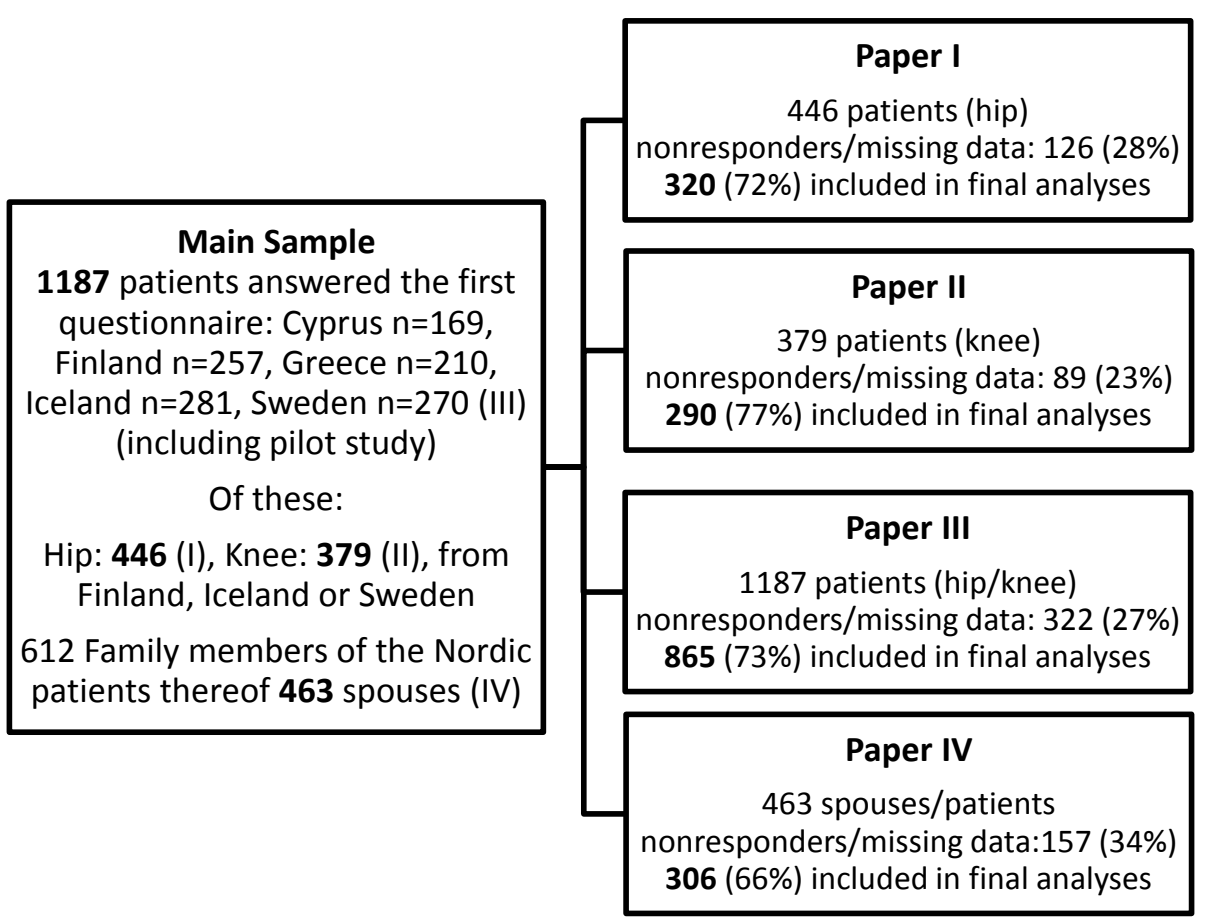

Figure 2. Overview of the main sample and the samples in papers I, II, III and IV 
Respondents that were willing to participate answered the first questionnaire (measurement one=M1) before surgery, and those who also answered questionnaires at discharge from hospital (measurement two=M2) were included in the final analyses of each paper. The instruments in each questionnaire are described in table 2. In paper I, 320 patients undergoing hip replacement and in paper II, 290 patients undergoing knee replacement were included. Paper III included 865 patients undergoing hip or knee replacement. In paper IV, 306 spouses and patients undergoing hip or knee replacement were included (table 1 and figure 2).

In the European project which this thesis is a part of, 1634 patients were included. That sample was based on power calculations of $\mathrm{EK}_{\mathrm{hp}}$ and $\mathrm{RK}_{\mathrm{hp}}$. The power level was 0.90 , and there was a 0.8 difference in mean scores, with 0.95 standard deviation within groups at the significance level of 0.01 . The required sample size for all seven countries included in the main project was at least 1540 patients, 220 patients per country (Valkeapää et al. 2014).

\section{Measurements}

Measurement one (M1) was carried out before surgery, and measurement two (M2) at discharge from hospital. An overview of the self-reported instruments included in these two questionnaires is presented for each paper in table 2, with an overview of their reliability in table 3.

Table 2. Instruments included in the questionnaires

\begin{tabular}{|c|c|c|c|c|c|}
\hline \multicolumn{2}{|c|}{ Variables and instruments } & \multirow{2}{*}{$\frac{\text { Paper I }}{\text { M1 }}$} & \multirow{2}{*}{$\begin{array}{l}\text { Paper II } \\
\text { M1 }\end{array}$} & \multirow{2}{*}{$\frac{\text { Paper III }}{\text { M1 }}$} & \multirow{2}{*}{$\begin{array}{l}\text { Paper IV } \\
\text { M1 }\end{array}$} \\
\hline $\begin{array}{l}\text { Knowledge Expectations, } \\
\text { hospital patients }\end{array}$ & $\mathrm{KE}_{\mathrm{hp}}$ & & & & \\
\hline $\begin{array}{l}\text { Knowledge Expectations, } \\
\text { significant others }\end{array}$ & $\mathrm{KE}_{\text {so }}$ & & & & $M 1^{a}$ \\
\hline Symptom scale & & M1 & & & \\
\hline Emotional state & & M1 & & M1 & $\mathrm{M} 2^{\mathrm{a}}$ \\
\hline $\begin{array}{l}\text { Preferences for information } \\
\text { and behavioural control }\end{array}$ & KHOS & & M1 & & \\
\hline Patient satisfaction with care & PSS & & $\mathrm{M} 2$ & $\mathrm{M} 2$ & \\
\hline Access to knowledge, patients & AKS & & $\mathrm{M} 2^{\mathrm{b}}$ & & \\
\hline Access to knowledge, spouses & AKS & & & & $\mathrm{M} 2^{\mathrm{ac}}$ \\
\hline Health-related Quality of life & EQ-5D & & & M1 & \\
\hline Quality of Recovery & QoR-40 & & & M2 & $\mathrm{M} 2$ \\
\hline $\begin{array}{l}\text { Received Knowledge, } \\
\text { hospital patients }\end{array}$ & $\mathrm{RK}_{\mathrm{hp}}$ & $\mathrm{M} 2$ & $\mathrm{M} 2$ & M2 & $\mathrm{M} 2$ \\
\hline $\begin{array}{l}\text { Received Knowledge, } \\
\text { significant others }\end{array}$ & $\mathrm{RK}_{\mathrm{so}}$ & & & & $\mathrm{M} 2^{\mathrm{a}}$ \\
\hline
\end{tabular}




\section{Reliability and validity}

The reliability of the used instruments was tested in each paper. The internal consistency of each sample is presented in table 3 .

Table 3. Overview of the reliability of the instruments in the papers

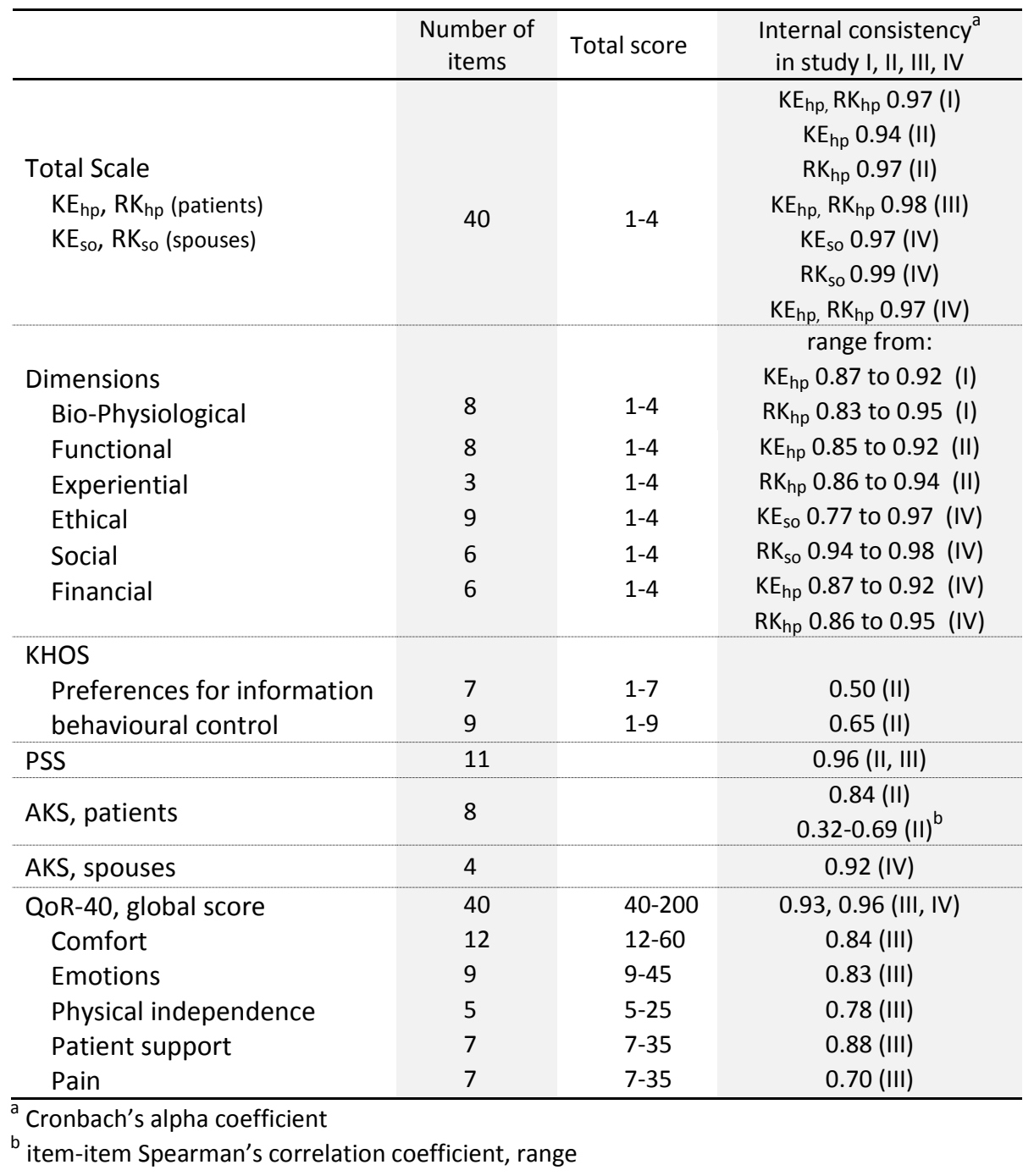

The instruments; QoR-40, EQ-5D, PSS and KHOS are widely used, and have been validated in a variety of settings, in several countries (Gornall et al. 2013, Krantz et al. 1980, Myles et al. 2000, Rabin \& de Charro 2001, Suhonen et al. 2012). $\mathrm{EK}_{\mathrm{hp}}$ and $\mathrm{RK}_{\mathrm{hp}}$ have been validated in a Finnish context (Heikkinen et al. 2007, Rankinen et al. 2007), and further validation is planned within the 
European project. The two versions of AKS, for patients and spouses, are parts of a validated instrument, Good Nursing Care Scale, (Leino-Kilpi \& Vuorenheimo 1994), but are not validated as single scales.

\section{Background data}

Background data were collected on patients' and spouses' characteristics: age, sex, educational level, employment status, and former or current employment in social service or healthcare. The patients were also asked whether they were undergoing hip or knee replacement, and if it was their first arthroplasty or not. They were also asked for the length of their present hospital stay and if their hospital stay had been as expected or not.

\section{Fulfilment of knowledge expectations}

Patients' fulfilment of knowledge expectations was measured with two structured instruments: Knowledge Expectations of hospital patients $\left(\mathrm{KE}_{\mathrm{hp}}\right.$ and Received Knowledge of hospital patients ( $\mathrm{RK}_{\mathrm{hp}}$ ) (I, II, III, IV). These are both 40-item scales with parallel questions, divided into six dimensions of knowledge: biophysiological (eight items e.g. knowledge about illness, symptoms, treatment, complications), functional (eight items e.g. mobility, rest, nutrition, bodily functions), experiential (three items e.g. emotions, hospital experiences), ethical (nine items e.g. rights, duties, participating in decision-making, confidentiality), social (six items e.g. support from family or community, social contact, patient organisations) and financial (six items e.g. costs, financial benefits). Each item is preceded with 'I expect knowledge on...' or 'I received knowledge about...' For the spouses in paper IV, Knowledge Expectations of significant others $\left(\mathrm{KE}_{\mathrm{so}}\right)$ and Received Knowledge of significant others $\left(\mathrm{RK}_{\mathrm{so}}\right)$ were used. The word 'mine' in $\mathrm{KE}_{\mathrm{hp}}$ and $\mathrm{RK}_{\mathrm{hp}}$ was replaced with 'my family member' in $\mathrm{KE}_{\mathrm{so}}$ and $\mathrm{RK}_{\mathrm{so}}$.

Response options for each item in $\mathrm{KE}_{\mathrm{hp}}, \mathrm{RK}_{\mathrm{hp}}, \mathrm{KE}_{\mathrm{so}}$ and $\mathrm{RK}_{\text {so }}$ were categorized from $1=$ fully disagree, to $4=$ fully agree, and $0=$ not applicable. The score for each dimension and the total scale are the mean value of included items, with a possible range of 1-4. When calculating these means the response option 'not applicable' was excluded. High scores indicated high knowledge expectations or a high level of received knowledge. The differences (i.e. empowering knowledge) were calculated by subtracting expected knowledge from received knowledge. The possible range was from -3 to 3 . Patients or spouses with no or a positive difference were defined as experiencing fulfilled knowledge expectations. A negative difference meant that patients or spouses had higher knowledge expectations than perceptions of received knowledge; 
these differences were defined as unfulfilled knowledge expectations. The instruments have been inductively developed, and have been reported to have good content validity and to be sufficiently psychometrically robust (Heikkinen et al. 2007, Klemetti et al. 2014, Leino-Kilpi et al. 2005a, Rankinen et al. 2007, Sigurdardottir et al. 2015, Valkeapää et al. 2014).

\section{Quality of Recovery}

Patients' Quality of Recovery was assessed by the validated 40-item instrument, QoR-40 (Gornall et al. 2013, Myles et al. 2000) which includes five dimensions of health; comfort (12 items e.g. breathe easy, good sleep, enjoy food, feeling restless), emotions (nine items e.g. feeling comfortable, anxious, depressed), physical independence (five items e.g. able to return to work or usual activities, have normal speech), patient support (seven items e.g. able to communicate, support from doctors, nurses, family or friends, feeling confused) and pain (seven items e.g. pain, headache, sore throat). Response options for each item ranged from $1=$ none of the time to $5=$ all of the time. For negative items the scale was reversed before analysis. The global score ranged from 40=extremely poor QoR to, 200=excellent QoR. The global score and the dimensions were reported in paper III; in paper IV the global score was reported.

\section{Access to knowledge}

The Access to Knowledge Scale (AKS) used for the patients (II) consists of eight statements about contact with and the sufficiency of information provided by nurses and doctors during hospitalisation. The statements cover matters such as how well the medical staff and nurses could answer the patient's questions and justify their actions, keep patients and significant others up to date with carerelated matters and provide patients with knowledge. The items in AKS are part of different theoretical components of the Good Nursing Care Scale (Leino-Kilpi \& Vuorenheimo 1994) which evaluates quality of care. Responses ranged between $1=$ fully disagree to $4=$ fully agree. Access to knowledge was represented by the mean score of included items of the AKS with the possible range of 1-4. Higher scores reflect better access to knowledge.

Spouses' opinions about Access to Knowledge (IV) were measured using four items from the Good Nursing Care Scale (Leino-Kilpi \& Vuorenheimo 1994). These statements were: a) The nurses explained sufficiently matters concerning my family members' care and treatment, b) The nurses had enough time for me, c) The doctors explained sufficiently matters concerning my family members' care and treatment, d) The doctors had enough time for me. Response 
options ranged from $1=$ fully disagree to $5=$ fully agree, where five indicated the best access to knowledge. The total score was the mean of the four items, which was treated as a scale, and a higher score reflected better access to knowledge. For family members Cronbach's alpha has been reported to be 0.94 (Sigurdardottir et al. 2015).

\section{Symptoms and emotions}

Patients prevalence and frequency of eight symptoms; pain, tiredness or fatigue, sleeplessness, sense of weakness, itching, breathlessness, loss of appetite, nausea or vomiting, were measured (I), as well as the prevalence and frequency of nine emotions; hope, concern, impatience, uncertainty, anxiety, fear, depressive state, grief, despair or hopelessness, of patients (I, III, IV) and their spouses (IV) (Heikkinen et al. 2012b). Response options were: 1=not at all, 2=rarely, $3=$ sometimes, $4=$ very often. Response options $\geq 2$ constituted the prevalence.

\section{Patient satisfaction with care}

The Patient Satisfaction Scale (PSS) was used to measure satisfaction with care (II, III). This 11-item instrument includes: components of care needs (technical/ scientific, information, and interaction/support) and evaluative criteria (accessibility, ability/competency and conduciveness). The response options were: 1=very dissatisfied, 2=dissatisfied, 3=satisfied, 4=very satisfied. Patient satisfaction was the mean score of the 11 items, and higher scores indicated more satisfaction with care. The instrument has been used in different European countries and has good psychometric properties (Suhonen et al. 2012).

\section{Preferences for information and behavioural control}

The Krantz Health Opinion Survey (KHOS) was used to measure patients' preferences about seeking health-related information, and about participation and control in decision-making regarding their own healthcare (II) (Krantz et al. 1980). The instrument has two subscales: preferences for information (KHOS-I), and behavioural involvement (KHOS-B) i.e. self-care and active participation. The maximum score is 7 for KHOS-I and 9 for KHOS-B. High scores reflect strong preferences for information or behavioural control. KHOS is reported to have satisfactory face and content validity, internal consistency and test-retest reliability (Krantz et al. 1980, Leino-Kilpi et al. 2009, Svedberg et al. 2012). 


\section{Health-related quality of life}

The generic instrument $E Q-5 D$, three level version, (EQ-5D-3L) was used to measure Health-Related Quality of life (HRQoL) (III). It is a validated instrument that has been used in several European countries and is recommended for orthopaedic patients (Goodwin et al. 2011, Rabin \& de Charro 2001). The instrument consists of two parts, the EQ visual analogue scale $(E Q V A S)$ with a vertical scale ranging from $0=$ worst imaginable health state, to $100=$ best imaginable health state, and the EQ-5D descriptive system including five dimensions: mobility, self-care, usual activities, pain/discomfort and anxiety/depression. Each dimension has three levels, 1=no problems, 2=some problems, $3=$ extreme problems. The EQ-5D scores were converted into a single summary $E Q-5 D$ index quantifying health status. The index ranges from -0.595 to 1 , and has 243 possible health outcomes. The higher the index score, the better the patient's perceived HRQoL.

\section{Procedures}

Ethical approvals were obtained in all countries before the data collection started. Translation procedures were performed, including back-translation of the information about the study and of the questionnaires. This was also done for instruments that did not already exist in the different languages. All eligible patients who met the inclusion criteria were invited to participate. The questionnaires were piloted with a group of 30 patients and their family members in each country.

Data were collected between 2009 and 2012 from patients and their family members in all participating countries in the European project at three different times; before surgery, at discharge from hospital and six months after discharge. In this thesis, data on patients and spouses from the first two measurements are used. The instruments that are included in the first (M1) and second (M2) questionnaire are described for each paper in table 2.

Information about the study, the principles of voluntary participation and confidentiality, and the first questionnaire were sent by staff nurses to the patient's home before admission to hospital, or handed out during admission, before counselling. The patients were asked to choose one family member and give them the package containing information, an informed consent form, and the first questionnaire. The family member could define themselves as a spouse, children or other. Patients were included in papers I, II and III, while spouses and patients were included in paper IV. Each of the patients and their spouses returned the signed informed consent form and completed questionnaires in 
prepaid envelopes to a member of the research groups in each country before they were included in the study.

Before the patients' discharge from hospital the second questionnaire was distributed. This questionnaire was returned to mailboxes on the ward or by prepaid envelopes to a member of the research groups. Patients could be offered help from family members or healthcare professionals to complete the questionnaires, for example by reading the questions.

Before admission, patients were provided with standard written information about the hospital stay and upcoming surgery, according to each hospital's standard procedures. During their hospitalisation they received further information and education according to standard procedures at each hospital. Spouses were generally welcome to participate in all parts of education, but they were not actively invited.

\section{Statistical analyses}

A summary of the statistical analyses in each paper is presented in table 1, page 23. Descriptive statistics were used to present the sample; frequencies and percentages for categorical variables, median and quartiles for ordinal variables, and mean values and standard deviation for continuous variables (I, II, III, IV).

To test the reliability of the instruments, Cronbach's alpha (I, II, III, IV), and item-item Spearman's correlation coefficient range (II) were used (table 3). The distribution was tested with Kolmogorov-Smirnov (I, II), or both visually and by Shapiro-Wilks test (III, IV) (Ghasemi \& Zahediasl 2012). The distribution of QoR-40 was skewed; therefore, it was normalized by using log transformation. After comparing the ordinary and normalized scales a decision was made on using the ordinary scale.

Group comparisons were tested with Chi-2 test for categorical variables, Mann-Whitney or Kruskal-Wallis for ordinal variables, and paired sample $t$-test, independent $t$-test, or one way ANOVA for continuous variables. Correlation analyses were conducted using Spearman's correlation coefficient for ordinal variables, and Pearson's correlation coefficient for continuous variables. Multicollinearity was tested with Variance Inflation Factor (VIF). For significant analyses, Kruskal-Wallis was followed by a post hoc Mann-Whitney test, and the ANOVA was followed by a post hoc Bonferroni correction (I, II, III, IV).

Additional analyses of data were carried out in the thesis. First, empowering knowledge was presented together for papers I and II as the result was equal for patients undergoing hip or knee replacement. Second, because different independent variables were used in the regression analyses in papers I and II, additional 
multiple stepwise regression analyses were carried out for each kind of arthroplasty. Empowering knowledge was still the dependent variable. All independent variables from papers I and II were used. These were; the prevalence of emotions at admission to hospital (concern, impatience, uncertainty, fear, anxiety, depressive state), country, professional education, employment in healthcare or social services, having their first arthroplasty or not, access to knowledge (AKS-scale), preferences for information (KHOS-I).

Internal missing data in the papers ranged between $0-9 \%$ and $0-13 \%$. In general, missing values were not replaced. Imputations were carried out for QoR (III, IV) according to the procedure manual (Myles 2009). Drop-out analyses were carried out in each of the papers.

The level of statistical significance was set at $p<0.05$. The Bonferroni correction was used when multiple comparisons were made (I, II, III, IV), as it established a more conservative significance level and therefore reduced the risk of type I error. The statistical analysis was performed by using IBM SPSS statistics for Windows, version 20-23.

\section{Ethical considerations}

Ethical considerations based on the World Medical Association Declaration of Helsinki (WMA 2013) were applied in every step of the research process. All relevant permissions and ethical approvals based on national standards in participating countries were obtained; Cyprus Y.Y.15.6.17.9 (2), Finland ETMK 102/180/2008, Greece 3029/17.08.2010, Iceland 09-084-SI, Sweden Dnr. M6909. Patients and spouses were informed of the purpose and procedures of the study, and about the principles of voluntary participation and confidentiality. They gave written informed consent.

A potential risk was emotional reactions when responding to questionnaires. Patients and their family members therefore had access to e-mail and phone numbers with a person in one of the research groups to discuss problems or reactions. There were no physical risks associated with the completion of the questionnaires. Even though the number of instruments was carefully considered to limit the number of questions, respondents might have experienced tiredness. Patients and spouses were therefore informed that they could answer the questions within a few hours, with an opportunity to rest. They were also offered help to complete the questionnaires if needed. All data were coded and stored safely, and to protect the integrity of the participants the number of persons who had access to participants' names and codes was limited. 


\section{Results}

The results are presented as summaries of the four papers, together with additional analyses. The first part focuses on fulfilment of knowledge expectations (I, II, III, IV), the second part on quality of recovery (III, IV). Overviews of the samples are presented in table 1 , and table 4.

\section{Sample characteristics}

The main sample was derived from the European research project; therefore patients' characteristics were similar, although some differences were found in the different samples. The mean age was between 64 and 67 years, and about $75 \%$ of the patients were having their first arthroplasty. Between $45 \%$ and $57 \%$ of the patients were women, while $54 \%$ of the spouses were women.

Table 4. Overview of the characteristics in the different samples

\begin{tabular}{|c|c|c|c|c|c|}
\hline & \multirow{2}{*}{$\begin{array}{l}\text { Paper I } \\
\text { Patients }\end{array}$} & \multirow{2}{*}{$\begin{array}{l}\text { Paper II } \\
\text { Patients }\end{array}$} & \multirow{2}{*}{$\begin{array}{l}\text { Paper III } \\
\text { Patients }\end{array}$} & \multicolumn{2}{|c|}{ Paper IV } \\
\hline & & & & Spouses & Patients \\
\hline $\begin{array}{l}\text { Three Nordic countries } \\
\text { Five European countries }\end{array}$ & 320 & 290 & 865 & \multicolumn{2}{|c|}{306} \\
\hline $\begin{array}{l}\text { Hip replacement, } n(\%) \\
\text { Knee replacement, } n(\%)\end{array}$ & 320 & 290 & $\begin{array}{l}413(48) \\
452(52)\end{array}$ & & $\begin{array}{l}152(50) \\
151(50)\end{array}$ \\
\hline Age in years, mean $( \pm S D)$ & $64( \pm 11)$ & $67( \pm 9)$ & $66( \pm 11)$ & $64( \pm 10)$ & $65( \pm 9)$ \\
\hline Female sex, $n(\%)$ & $177(55)$ & $152(52)$ & $493(57)$ & $163(54)$ & $136(45)$ \\
\hline \multicolumn{6}{|l|}{ Professional education, $n(\%)$} \\
\hline None & $77(26)$ & $82(28)$ & $369(47)$ & $76(29)$ & $63(24)$ \\
\hline Secondary level & $71(24)$ & $74(26)$ & $179(23)$ & $82(31)$ & $84(32)$ \\
\hline College level & $74(25)$ & $56(19)$ & $136(17)$ & $59(22)$ & $66(25)$ \\
\hline Academic level & $53(18)$ & $39(13)$ & $96(12)$ & $47(18)$ & $52(20)$ \\
\hline \multicolumn{6}{|l|}{ Employment status, $n(\%)$} \\
\hline Employed & $146(46)$ & $89(31)$ & $263(31)$ & $131(44)$ & $125(42)$ \\
\hline Retired & $154(49)$ & $172(59)$ & $462(55)$ & $150(50)$ & $154(51)$ \\
\hline Other & $16(5)$ & $23(8)$ & $114(14)$ & $17(6)$ & $22(7)$ \\
\hline $\begin{array}{l}\text { Having a history of employment in } \\
\text { social service or healthcare, } n(\%)\end{array}$ & $81(26)$ & $76(26)$ & $153(18)$ & $65(22)$ & $84(28)$ \\
\hline First arthroplasty, $n(\%)$ & $244(76)$ & $210(72)$ & $632(74)$ & & $227(75)$ \\
\hline Hospital stay in days, mean ( \pm SD) & $6( \pm 5)$ & $6( \pm 3)$ & $8( \pm 6)$ & & $6( \pm 2)$ \\
\hline
\end{tabular}

Patients undergoing hip replacement were significantly younger (I, II, III, $p<0.01$ ), a lower proportion were women (III, $p<0.05$ ), and they had a higher level of education (I, II, III, $p<0.01$ ), compared with those undergoing knee replacement. A longer hospital stay was found in paper III where five countries 
were included compared with papers I, II and IV, where the three Nordic countries were included $(p<0.01)$.

\section{Fulfilment of knowledge expectations}

Patients had high knowledge expectations that had not been fulfilled during the hospital stay (I, II, III, IV). The mean differences between received and expected knowledge, total scale, are presented per country in figure 3 , and per dimension in figure 4. A negative value of these differences means higher knowledge expectation than received knowledge, defined as unfulfilled knowledge expectations.

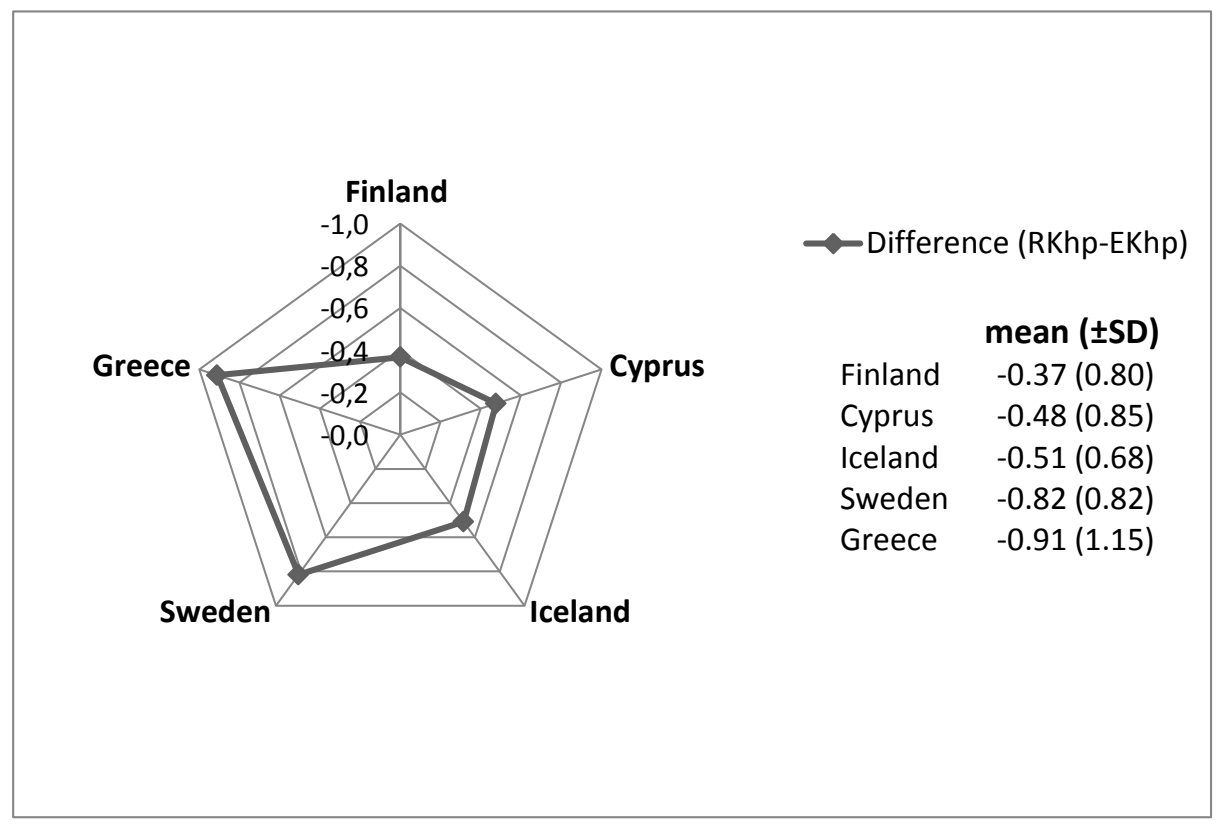

Figure 3. Patients' fulfilment of knowledge expectations, per country (III)

Fulfilment of knowledge expectations was equal for both kinds of arthroplasty (III), as was also the case in the Nordic countries (I, II). The different dimensions of empowering knowledge for the samples in papers I and II are therefore presented together (figure 4). The mean differences between received and expected knowledge were significant $(p>0.001)$ for all dimensions, and for the total scale of empowering knowledge. 


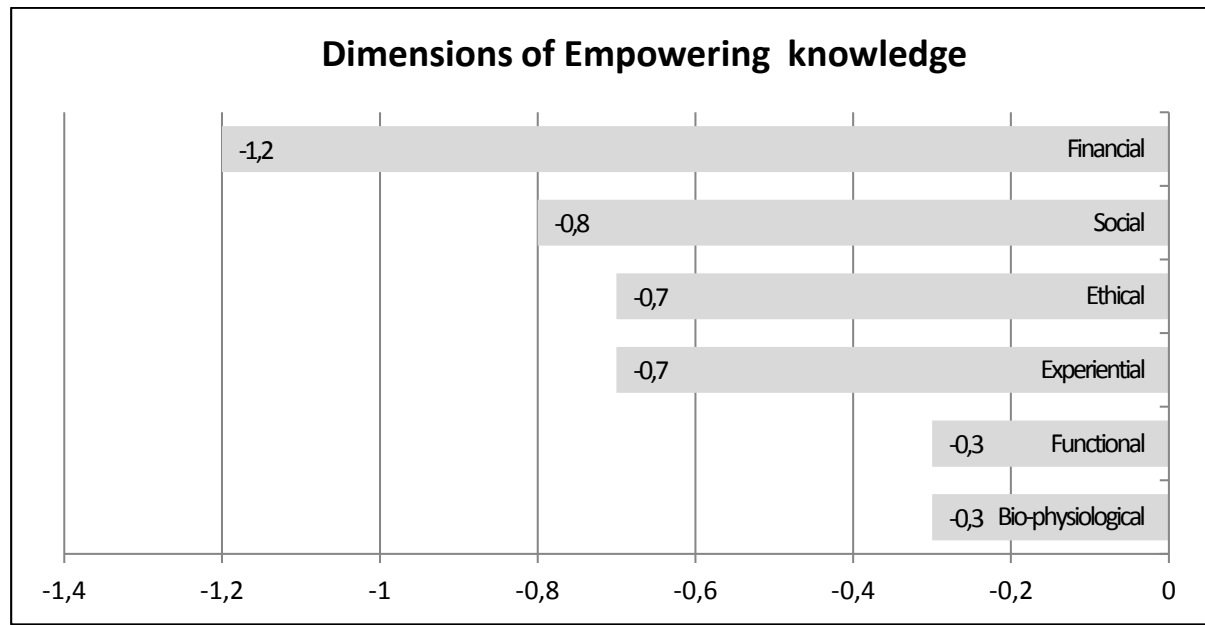

Figure 4. Patients' fulfilment of knowledge expectations in the dimensions of empowering knowledge, Nordic countries, $n=610$ : hip=320 (I) knee=290 (II)

The greatest mean difference between received and expected knowledge among patients was in the financial dimension, and the smallest was in the biophysiological and functional dimensions of knowledge (I, II) (figure 4).

The total mean difference for the patients was greater in Sweden $-0.98( \pm \mathrm{SD}$ 0.76), compared with Iceland $-0.67(0.72)$ and Finland $-0.46(0.80), p<0.001$ (I, II). These comparisons between the countries were analogous to the patients $(p<0.001)$, and the spouses $(p<0.001)$ in paper IV (figure 5).

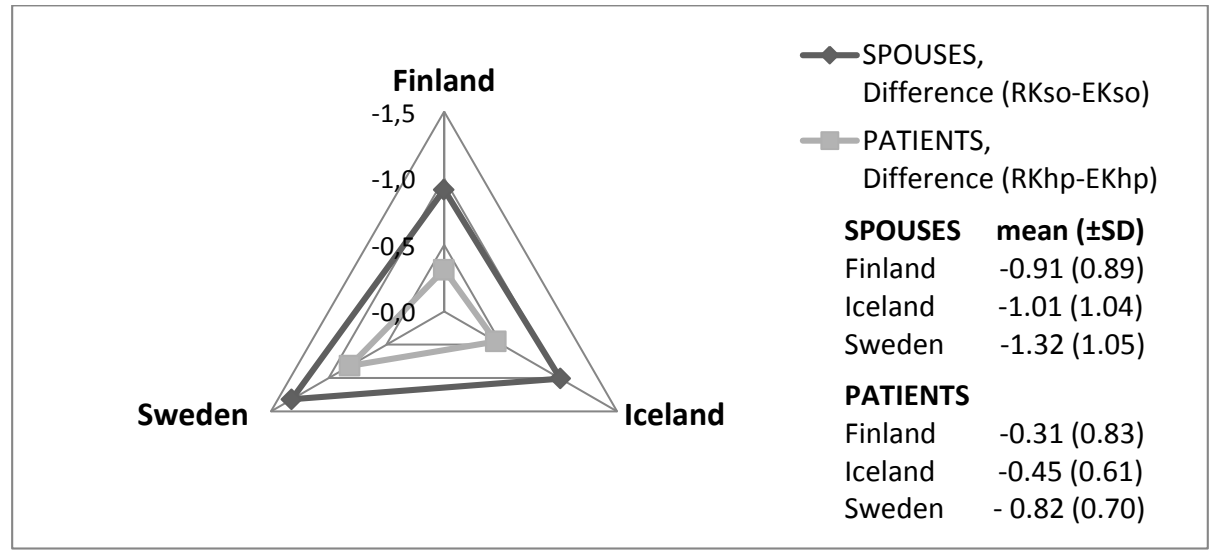

Figure 5. Spouses' and patients' fulfilment of knowledge expectations, total scale per country (IV) 
The knowledge expectations were similar for the spouses (mean 3.6, $\pm \mathrm{SD}$ 0.5 ) and the patients (mean 3.6, \pm SD 0.4 ), while spouses had significantly less fulfilled knowledge expectations compared with the patients for the total scale $(p<0.001)$ (figure 5). The differences between spouses and patients in fulfilment of knowledge expectations were significant for all dimensions of empowering knowledge $(p<0.001)$ (figure 6).

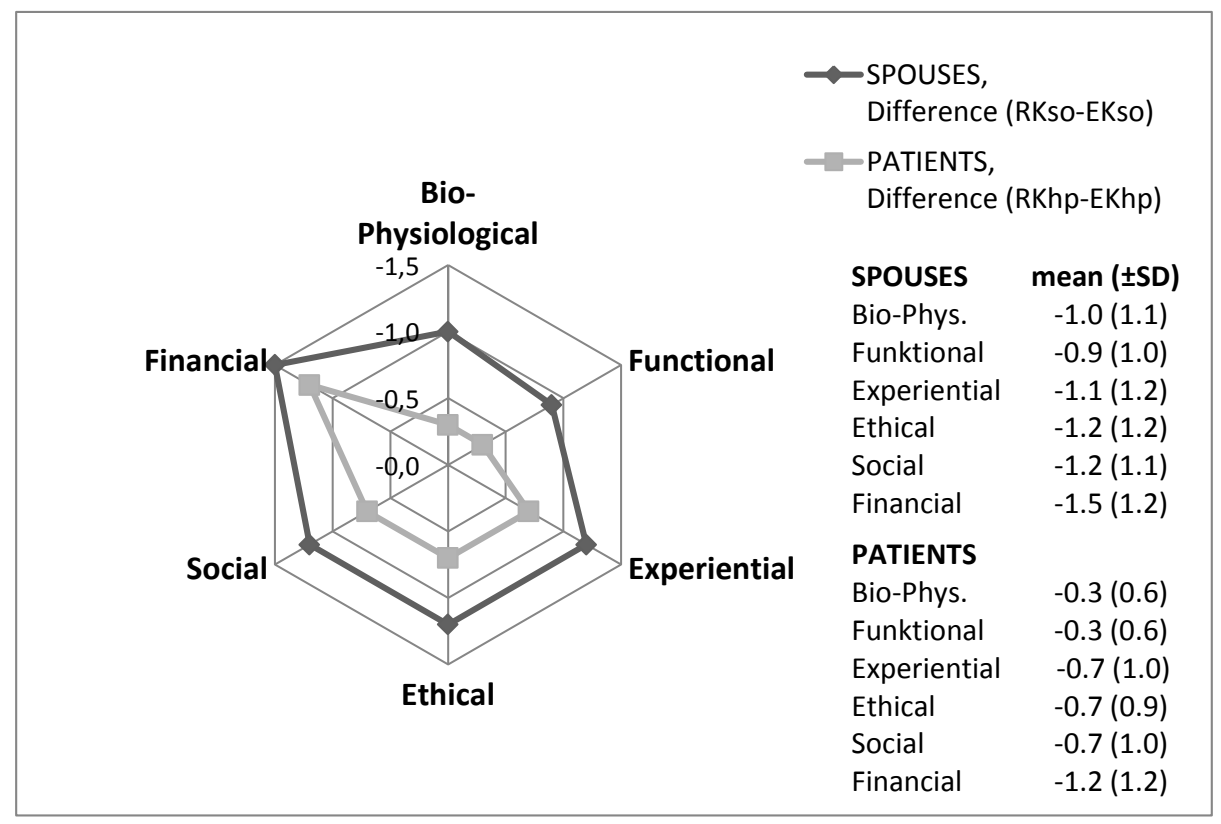

Figure 6. Spouses' and patients' fulfilment of knowledge expectations in the dimensions of empowering knowledge (IV)

The differences between spouses and patients were greatest in the biophysiological and functional dimension (mean $-0.7, \pm$ SD 1.1), and lowest in the financial dimension of knowledge (mean $-0.3, \pm$ SD 1.4) (IV) (figure 6).

\section{Background factors related to fulfilment of knowledge expectations}

As presented above, country was related to fulfilment of knowledge expectations for both kinds of arthroplasty (I, II) (figures 3 and 5). In addition, patients who experienced the hospital stay as meeting their general expectations had more fulfilled knowledge expectations compared with those who did not $(p<0.001)$ (I, II). The other related background factors differed between patients undergoing hip or knee replacement; for patients undergoing hip replacement (I) those with a higher level of professional education had less fulfilled knowledge expectations 
( $p<0.001$ ). Patients undergoing knee replacement (II) and having their first arthroplasty had less fulfilled knowledge expectations compared with patients with previous experience of arthroplasty $(p<0.05)$. Those who had been employed in healthcare or in the social services also had more unfulfilled knowledge expectations $(p<0.05)$ (II).

\section{Factors associated with fulfilment of knowledge expectations}

Depressive state was the major predictor and could explain $16.2 \%$ of the variance in fulfilment of knowledge expectations for patients undergoing hip replacement (I). For patients undergoing knee replacement, the major predictor, access to knowledge, could explain $29.7 \%$ of the fulfilment of knowledge expectations (II). In total, the models explained $22.1 \%$ (I) and $33 \%$ (II) of the variance.

Different independent variables were selected in the regression models that are presented above (I, II). To gain a better understanding of empowering knowledge, secondary analyses were carried out for each kind of arthroplasty, adding all the independent variables used in papers I and II. The results from these multiple stepwise regressions in which both emotional state, and access to knowledge are added, are presented in tables 5 and 6.

Table 5. Hip replacement, variables predicting the fulfilment of knowledge expectations

\begin{tabular}{lccccc}
\hline Variable & $B$ & S.E. & Beta & $t$-value & $p$-value \\
\hline Access to knowledge $^{\mathrm{a}}$ & .709 & .072 & .523 & 9.903 & $<.001$ \\
Depressive state $^{\mathrm{b}}$ & -.237 & .086 & -.153 & -2.767 & .006 \\
Professional education $^{\mathrm{c}}$ & -.089 & .035 & -.127 & -2.508 & .013 \\
Fear $^{\mathrm{b}}$ & -.182 & -.089 & -.111 & -2.053 & .041 \\
\multicolumn{1}{c}{ Constant } & .814 & .122 & & 6.645 & $<.001$ \\
\hline
\end{tabular}

$R^{2}=.421$, adjusted $R^{2}=.411, F=42.103 \mathrm{df}(4,232), p=<0.001$

${ }^{a}$ Scale ranged between 1 to 4 , higher scores reflect better access to knowledge

${ }^{\mathrm{b}} 0=$ not at all $1=$ rarely, sometimes, very often

${ }^{\mathrm{c}} 0=$ none, $1=$ secondary level, $2=$ college level, $3=$ =academic level 
Table 6. Knee replacement, variables predicting the fulfilment of knowledge expectations

\begin{tabular}{lccccc}
\hline Variable & $B$ & S.E. & Beta & $t$-value & $p$-value \\
\hline Access to knowledge $^{\mathrm{a}}$ & .802 & .084 & .516 & 9.557 & $<.001$ \\
Impatience $^{\mathrm{b}}$ & -.346 & .096 & -.196 & -3.582 & $<.001$ \\
Employed in healthcare $^{\mathrm{c}}$ & -.249 & .094 & -.149 & -2.736 & .007 \\
Country $^{\mathrm{d}}$ & -.112 & .051 & -.119 & -2.173 & .031 \\
$\quad$ Constant & 1.204 & .174 & & 6.921 & $<.001$
\end{tabular}

$R^{2}=.359$, adjusted $R^{2}=.347, F=31.057 \mathrm{df}(4,222), p=<0.001$

${ }^{\text {a }}$ Scale ranged between 1 to 4 , higher scores reflect better access to knowledge

${ }^{\mathrm{b}} 0=$ not at all $1=$ rarely, sometimes, very often

${ }^{c} 0=$ No, $1=$ Yes

d $1=$ Finland, 2=Iceland, 3=Sweden

The new models could explain $41.1 \%$ of the variance in fulfilment of knowledge expectations for patients undergoing hip replacement and $34.7 \%$ of the variance for knee replacement (tables 5 and 6). The major predictor for both kinds of arthroplasty was access to knowledge, which could explain $36.2 \%$ of the variance for patients undergoing hip replacement and $26.9 \%$ for knee replacement. Patients' emotional state, such as depressive state or impatience, was also a predictor. No multicollinearity was found for any of the variables, VIF range from 1.020 to 1.223 (hip), and from 1.006 to 1.041 (knee).

\section{Patients Quality of Recovery}

At discharge from hospital the global score of QoR was $165.7( \pm$ SD 22.3) for the patients in the European sample (III), and 169.2 ( \pm SD 18.8) in the Nordic sample (IV) (Figure 7).

In both samples, patients with fulfilled knowledge expectations experienced significantly greater QoR compared with those experiencing unfulfilled knowledge expectations (III: $p=0.012$, IV: $p=0.035$ ). No significant difference was found between patients undergoing hip or knee replacement for the global score (III: $p=0.187$ ). 

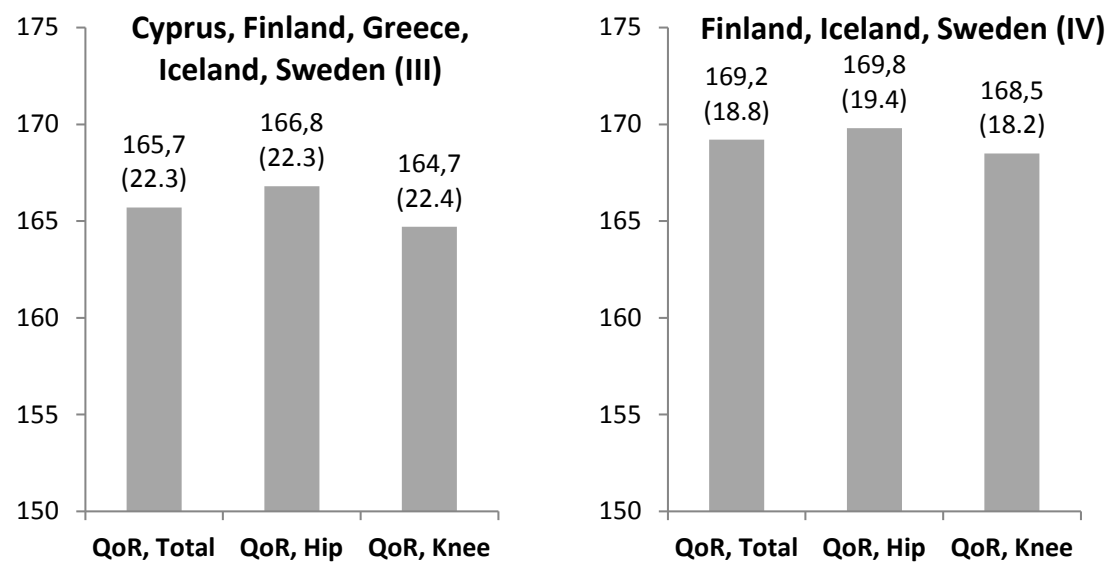

Figure 7. Patients' Quality of Recovery, global score, in the European (III) and Nordic samples (IV), mean, ( \pm SD)

Patients in Cyprus had significantly poorer QoR compared with patients from the other four countries $(p<0.001)$. Icelandic patients had higher QoR compared with Swedish patients (hip: $p<0.001$, knee: $p=0.005$ ) (Figure 8).

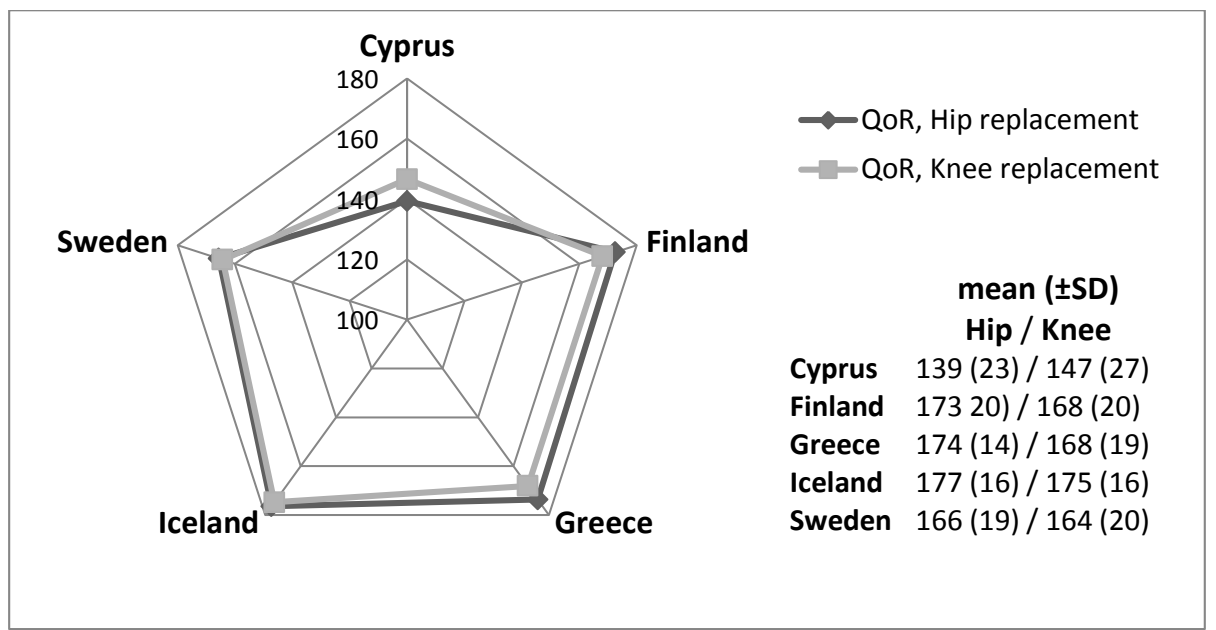

Figure 8. QoR for patients undergoing hip or knee replacement, total scale per country (III)

When comparing QoR between patients undergoing hip or knee replacement, Greek patients undergoing hip replacement had significantly higher QoR $(p=0.030)$ compared with those undergoing knee replacement (III) (figure 8). 
At discharge from hospital, QoR for the different dimensions was close to the maximum score for both kinds of arthroplasty (figure 9).

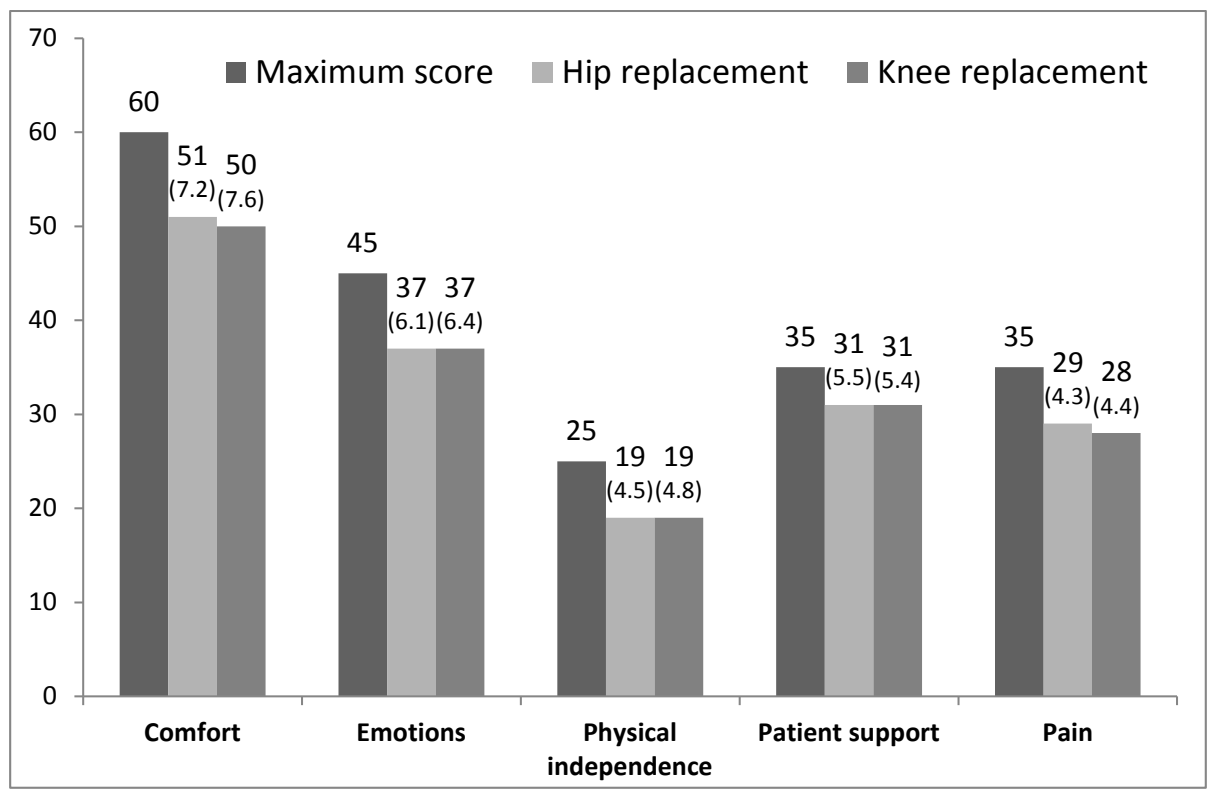

Figure 9. The dimensions of QoR, and comparisons between patients undergoing hip or knee replacement (III), maximum scores, mean ( $\pm S D$ )

In the dimension of pain, patients undergoing hip replacement had significantly higher QoR compared to patients undergoing knee replacement (hip: $29.0( \pm 4.3)$, knee: $28.3( \pm 4.4), p=0.025)$.

\section{Variables predicting the Quality of Recovery}

Greater satisfaction with care was the main predictor of better QoR (III). For patients undergoing hip replacement, $52.2 \%$ of the variance in QoR could be explained by: satisfaction with care, whether the hospital stay was realised as expected, length of hospital stay, and despair or hopelessness. For patients undergoing knee replacement, $43.9 \%$ of the variance could be explained by satisfaction with care.

Spouses' experiencing uncertainty, depressive state or if they had a history of employment in social services or healthcare, were associated with lower QoR. Whether nurses explained matters concerning the care and treatment to the spouses were associated with greater QoR. These spouse-related factors explained $18.3 \%$ of the variance in patients' QoR. The main predictor, uncertainty, explained $11.6 \%$ of the variance (IV). 


\section{Summary of the results}

Patients and spouses expected more knowledge than they received. Knowledge expectations were similar, while spouses had less fulfilled knowledge expectations, compared with the patients. Swedish patients and spouses had less fulfilled knowledge expectations compared with Icelandic and Finnish patients and spouses. An overview of the result, and factors associated with empowering knowledge and QoR is presented in figure 10 .

\begin{tabular}{|c|c|c|c|}
\hline $\begin{array}{c}\text { Background factors } \\
\text { of patients (I, II) }\end{array}$ & $\begin{array}{c}\text { Empowering } \\
\text { knowledge }\end{array}$ & $\begin{array}{l}\text { Background factors of } \\
\text { patients (III), and } \\
\text { spouses (IV) }\end{array}$ & QoR \\
\hline $\begin{array}{c}\text { DEMOGRAPHICS } \\
\text { - Level of professional } \\
\text { education was } \\
\text { negatively associated } \\
\text { with empowering } \\
\text { knowledge (Hip) } \\
\text { PERSONAL FACTORS } \\
\text { - Emotional state was } \\
\text { negatively associated } \\
\text { with empowering } \\
\text { knowledge (Hip/Knee) } \\
\text { - Employment in social } \\
\text { service or healthcare } \\
\text { was negatively } \\
\text { associated with } \\
\text { empowering knowledge } \\
\text { (Knee) } \\
\text { KNOWLEDGE } \\
\text { - Access to knowledge } \\
\text { was positively associated } \\
\text { with fulfilment of } \\
\text { knowledge expectations } \\
\text { (Hip/Knee) } \\
\text { empowering knowledge } \\
\text { (Knee) } \\
\text { associated with }\end{array}$ & $\begin{array}{l}\text { - In general, } \\
\text { knowledge } \\
\text { expectations } \\
\text { were not } \\
\text { fulfilled } \\
\text { - Spouses had } \\
\text { less fulfilled } \\
\text { knowledge } \\
\text { expectations } \\
\text { compared with } \\
\text { patients }\end{array}$ & $\begin{array}{c}\text { CLINICAL FACTORS } \\
\text { - Length of hospital stay was } \\
\text { negatively associated with } \\
\text { QoR (Hip) } \\
\text { PERSONAL FACTORS } \\
\text { - Patients' satisfaction with } \\
\text { care was positively } \\
\text { associated with QoR } \\
\text { (Hip/Knee) } \\
\text { - Patients' experience of } \\
\text { hospital stay meeting their } \\
\text { expectations was positively } \\
\text { associated with QoR (Hip) } \\
\text { - Spouses experiencing } \\
\text { uncertainty or depressive } \\
\text { state was negatively } \\
\text { associated with patients } \\
\text { QoR (Hip/Knee) } \\
\text { - Spouses' history of } \\
\text { employment in social } \\
\text { service or healthcare was } \\
\text { positively associated with } \\
\text { patients' QoR (Hip/Knee) } \\
\text { KNOWLEGE } \\
\text { knowledge from nurses was } \\
\text { - Spouses access to } \\
\text { QoR (Hip/Knee) } \\
\text { - COUNTRY was associated } \\
\text { with QoR }\end{array}$ & $\begin{array}{l}\text {-In general } \\
\text { QoR was } \\
\text { similar for } \\
\text { the two } \\
\text { kinds of } \\
\text { arthro- } \\
\text { plasty }\end{array}$ \\
\hline
\end{tabular}

Figure 10. Summary of the results, background factors associated with empowering knowledge and Quality of Recovery 
The major predictor of patients' empowering knowledge was access to knowledge. This association was positive, which means that higher access to knowledge was associated with better fulfilment of knowledge expectations. Patients' emotional state, such as depressive state, impatience or fear was associated with less fulfilment of knowledge expectations.

Patients' experience of greater satisfaction with care was associated with greater QoR. Spouses' uncertainty or depressive state was associated with lower QoR. If the nurses explained matters concerning the patient's care and treatment sufficiently for the spouses, patients experienced greater QoR. 


\section{Discussion}

\section{Discussion of the results}

This thesis is the first to explore the associations between empowering knowledge and QoR. The most important result that might improve patients' QoR was that the emotional state of patients and their spouses plays an important role in fulfilment of knowledge expectations and also in better QoR, and that greater satisfaction with care was associated with greater QoR.

\section{Empowering knowledge}

Patients and spouses expected more knowledge than they received during the hospital stay (I, II, III, IV). This means that the knowledge they received might not support their empowering process sufficiently for them to have an active role during the recovery process. Results from the European project showed that, in general, patients in the Nordic countries expected more knowledge than those in the southern countries (Valkeapää et al. 2014). No such differences were found on fulfilment of knowledge expectations in paper III, where patients from Sweden and Greece experienced the least fulfilment of knowledge expectations, and patients from Finland, Cyprus and Iceland had the highest. This result corresponds with the results from the European project, where Sweden and Greece also had the least fulfilment knowledge expectations, while Finland and Lithuania had the highest (Klemetti et al. 2014). Even though patients in the Nordic countries had higher knowledge expectations compared with the southern European countries, the fulfilment of knowledge expectations did not seem to differ between the north and the south of Europe.

Patients' knowledge expectations were best fulfilled in the bio-physiological and functional dimensions of knowledge and least in the financial dimension (I, II, IV). These results are in line with the results of other studies, for example in the orthopaedic, surgical and oncologic context (Heikkinen et al. 2007, Klemetti et al. 2014, Rankinen et al. 2007, Vaartio-Rajalin et al. 2014). No significant differences in fulfilment of knowledge expectations were found between patients undergoing hip or knee replacement (I, II). A strong association has recently been found between received knowledge and the quality of care provided by nurses. The strongest positive correlations were found between the quality of care and the bio-physiological and experiential dimensions, while the weakest was found 
for the financial dimension (Leino-Kilpi et al. 2014). Thus, improvements in fulfilment of knowledge expectations are possible if the quality of care improves, especially in the bio-physiological and experiential dimensions.

A challenge that seems to remain is how knowledge expectations in the financial, social and ethical dimensions should be fulfilled. The theoretical basis of EPE emphasises the individuals' capacity, and the content of the education should meet their personal educational needs in all dimensions of knowledge. This was not the case in studies I and II, which concluded that patients lack empowering knowledge in all dimensions, and spouses lack even more knowledge compared with the patients (IV). It has been shown that patients undergoing hip or knee replacement need multidimensional knowledge that covers a broad range of topics, from those addressing practical aspects of daily living, to those related to the healthcare system (Soever et al. 2010).

This thesis does not evaluate existing patient education as the information and education were delivered according to standard procedures at each hospital. Nevertheless, the results suggest a development of current patient education. The outcome of patient education in the orthopaedic context has diverse results. Educational interventions have been shown to have no effect on pain, or rehabilitation, after hip and knee replacement (Louw et al. 2013, van den AkkerScheek et al. 2007). Positive effects have been found in the level of knowledge and independency on activities in daily living, and patients' also experienced fewer problems (Demir \& Erdil 2013), and shorter hospital stays (Yoon et al. 2010). Some interventions had both positive and negative outcomes, such as improving patients' knowledge but with no difference in anxiety levels (Fraval et al. 2015, Heikkinen et al. 2012a, Heikkinen et al. 2012b). In another study, patients were better prepared for surgery and to control postoperative pain, but no differences in factors such as length of hospital stay, level of pain or complication rate were found (Kearney et al. 2011). These earlier studies give limited guidelines for designing an empowering educational intervention. Further research is therefore needed to find out how EPE, with the goal of improving patients' QoR can be provided.

The additional analyses of the samples in papers I and II could explain more of the variance in fulfilment of knowledge expectations for patients undergoing hip or knee replacement, compared with the results presented in the papers. The aims of papers I and II were different and the additional analyses were carried out to find possible similarities and differences between the two kinds of arthroplasty. Therefore, all independent variables used in papers I and II were added to new regression models. For patients undergoing hip replacement the main predictor changed from depressive state to access to knowledge. Depressive state remained as a predictor, and fear was added. For patients undergoing knee 
replacement, access to knowledge remained as the main predictor and impatience was added as a predictor. The new models could explain $41.1 \%$ (hip) and $34.7 \%$ (knee) of the variance in empowering knowledge, compared with $22.1 \%$ for hip replacement and $33 \%$ for knee replacement (I, II). Access to knowledge was also the main predictor of empowering knowledge for the family members in the European project (Sigurdardottir et al. 2015). It is not a surprise that access to knowledge was the main predictor of fulfilment of knowledge expectations. These two variables have a clear connection; if patients have access to knowledge their knowledge expectations are probably met. Differences in associated factors between the two kinds of arthroplasty were found in the additional analyses, as well as in papers III and IV, which emphasises the importance of identifying individuals in need of personalised patient education.

For both kinds of arthroplasty, patients experiencing negative emotions such as depressive state, impatience or fear experienced less fulfilled knowledge expectations (I, II). Assessment of patients' emotional state before surgery would therefore help nurses to identify those at risk of having their knowledge expectations unfulfilled. On the other hand, self-reported scales measuring the prevalence and frequency of emotional state only offer a glimpse into the nature and severity of a person's psychological state. Nurses play a meaningful role in the management of anxiety, but there is limited research on how interventions could be adapted to the underlying cause of anxiety (Zweers et al. 2015). Patients' knowledge expectations were not fulfilled in the experiential dimension including items about their emotions (I, II). Negative emotions will probably not be reduced just by providing knowledge on how the illness and its treatment could affect patients emotionally, and who the patient can talk with about these matters. This problem is complex and further research is needed to find out how interventions can facilitate positive changes in emotional state among patients undergoing hip or knee replacement.

\section{Quality of Recovery}

Patients' emotional state was not only a predictor of empowering knowledge (I, II), it was also one of the factors related to QoR (III). Patients experiencing feelings such as preoperative despair or hopelessness, concern or depressive state had poorer QoR at discharge compared with those not experiencing such negative emotions. Despair or hopelessness could also explain the variance in QoR, but only for patients undergoing hip replacement (III). A qualitative study of day surgery patients has shown that a positive attitude combined with confidence in the situation favoured the recovery (Berg et al. 2013), and patients without depression, undergoing knee replacement, have been shown to have 
better functional outcome (Caracciolo \& Giaquinto 2005). A reduction in preoperative anxiety, depressive symptoms and uncertainty has been shown to have a positive impact on postoperative recovery (Duivenvoorden et al. 2013, Kagan \& Bar-Tal 2008). A positive emotional state has also been shown to facilitate discharge after orthopaedic surgery. Health professionals should therefore be aware that loss of independence and the ability to cope with pain can influence the emotional state, and consequently patients' recovery (Perry et al. 2012). Not only patients' but also spouses' experiences of negative emotions at discharge from hospital were associated with patients' QoR (IV). The findings in studies III and IV together with the results from earlier research suggest that patients may improve their QoR by preoperative interventions promoting a more positive emotional state among patients and their spouses. Patients with fulfilled knowledge expectations experienced better QoR (III); therefore, EPE might improve QoR after hip or knee replacement. As discussed earlier, negative emotions will not be reduced only by providing knowledge; therefore, additional interventions with the goal of promoting a more positive emotional state need to be developed.

The relevance of emotional state has also been highlighted as a predictor of postoperative pain after hip or knee replacement since preoperative optimism has been found to be the main predictor of postoperative pain intensity (Pinto et al. 2013). Despite a worse preoperative health state, patients undergoing hip replacement showed better QoR in the dimension of pain, compared to those undergoing knee replacements (III). This finding however, is different compared with earlier studies, which have shown greater overall improvements for patients undergoing hip replacement compared with those undergoing knee replacements, and this also occurs in the early period of recovery (Choi et al. 2012, de Beer et al. 2012, O'Brien et al. 2009). Further research is needed to find out why these differences in QoR are smaller between hip and knee arthroplasty patients in our multi-centre, cross-cultural study compared with earlier single-centre studies. It has been concluded that analgesic needs are higher for patients undergoing knee replacement than those undergoing hip replacement. This means that patients undergoing hip replacement have less postoperative pain (Anastase et al. 2014). It is possible that the smaller differences in our study are related to less pain, since new analgesia methods and operative techniques aimed at early mobilization and shorter hospital stay have been developed during recent years (Anastase et al. 2014). It is also possible that the multi-centre, cross-cultural design might hide differences in QoR within and between the countries. Cypriot patients undergoing hip replacement had lower QoR compared with those undergoing knee replacements. The result was the opposite in the other four countries, but a significant difference between the two kinds of arthroplasty was 
only found in Greek patients. Cypriot patients also had significantly poorer QoR compared to patients from the other four countries (III). Possible reasons for these differences between the countries might be differences in the healthcare systems, different indication criteria, the population age structure (OECD 2014), and the level of family support during the recovery process.

Patients were least satisfied with the way nurses prepared their families before discharge from hospital (II). Patients experienced better QoR if nurses had enough time and explained matters concerning the patients' care and treatment sufficiently for their spouses, while access to physicians' knowledge was not related to, or associated with the patients' QoR (IV). This result emphasises the importance of the information and education obtained from nurses.

In the European project, spouses had less access to knowledge and experienced more unfulfilled knowledge expectations compared with the patients' children. Spouses also had less desire to seek health-related information compared with the patients' children (Sigurdardottir et al. 2015). That spouses feel less informed than adult children during the discharge process has also been found in another Nordic study (Bragstad et al. 2014). In the Nordic countries, family members had more unfulfilled knowledge expectations and less access to knowledge from healthcare providers compared with family members from the southern European countries (Sigurdardottir et al. 2015). Due to today's short hospital stays, spouses play an important role during the recovery process, and should therefore be seriously taken into account by healthcare professionals and be provided with empowering knowledge, especially in the Nordic countries.

A greater involvement of family care has been reported in southern, compared with northern Europe (Lamura et al. 2008, Sapountzi-Krepia et al. 2008), and there are more nurses per population in the Nordic countries compared with southern Europe. On average there were about eight nurses per 1000 population, across EU countries in 2012. While the numbers of practicing nurses were about 14 in Finland, 15 in Iceland and 11 in Sweden, compared with about five in Cyprus and four in Greece (OECD 2014). More traditional family values in southern Europe are a possible explanation for the greater involvement in family care. Another reason for greater family involvement might be that the numbers of nurses in Cyprus and Greece is about 1/3 compared with the Nordic countries. Even though there are fewer nurses in southern Europe, they are better at providing family members with knowledge (Sigurdardottir et al. 2015). It is possible that family members in Cyprus and Greece spend more time at hospital compared with family members from the less family-dependent and more individualised Nordic countries of Finland, Iceland and Sweden (Berggren et al. 2011, Charalambous et al. 2014, Johansson et al. 2011). 
An interesting result was that QoR was higher for patients who also had a spouse included in the study (IV), compared with the sample where all patients were included also those without a spouse or other family member included in the study (III). This result indicates that spousal support might be an important factor influencing patients' QoR. The effect of spousal support during the recovery period after discharge from hospital would therefore be an important research area.

\section{Improving patients Quality of Recovery}

Patient education has been shown to result in an increased level of knowledge; it is closely linked to the recovery process and promotes early recovery (Murphy et al. 2011, Tay Swee Cheng et al. 2015). Patients undergoing hip or knee replacement are often treated together, and the results of this thesis highlight the necessity to develop care that is customised to meet patients' personal needs, regardless of operative intervention. The results may help nurses to identify factors related to QoR among the patients and their spouses. These factors can be related to patients' or their spouses' demographics, their level of empowering knowledge, clinical factors such as kind of arthroplasty, or personal factors such as emotional state or spousal support. They can also be related to differences between the countries. Greater satisfaction with care was the main predictor of QoR (III). If patients' satisfaction with care can be improved by person-centred care, it may be possible to improve the period of recovery in the patient's home environment (Ulin et al. 2015).

As better access to knowledge among the patients was associated with more fulfilled knowledge expectations, it is clearly possible to improve patients' empowering knowledge by education. If healthcare professionals identify patients with a negative emotional state and a higher level of professional education, and make special efforts to support them in fulfilling their individual knowledge expectations in all dimensions of empowering knowledge, empowerment might be achieved. It is possible that knowledge expectations vary over time, as they do in the oncologic context, where they have been shown to be affected by personal, situational, and clinical factors (Vaartio-Rajalin et al. 2015). Person-centred care may meet this challenge. EPE takes patients' level of knowledge, abilities, attitudes and values into account when providing education. When using person-centred care, patients can feel empowered to be involved in their own health decisions throughout the whole recovery process.

In structured, person-centred admission and discharge planning, patients' resources and social situation are identified. This means that spouses are included in the patients' narrative and become a part of the shared health plan (Ulin et al. 
2015). This collaboration with spouses as informal caregivers facilitates a safe return to home if patients need support during the postoperative recovery process.

The importance of the culture and context of care has been highlighted in an intervention to promote person-centred care (Laird et al. 2015). A review has concluded that person-centred care is in danger of losing its original humanistic emphasis if sufficient attention is not paid to best practices grounded in the concept of personhood. Without understanding the concept of personhood there is a danger that the essence of personhood may be lost in the zeal to implement a popular model or framework (McCormack et al. 2012). If EPE is provided with the humanistic view of personhood, patients and their spouses have a better opportunity to become empowered, which might improve patients' QoR after hip or knee replacement.

\section{Methodological discussion}

The large sample together with validated and reliable instruments used, ensure the papers are of good quality (Polit \& Beck 2012). The multi-centre design increased the number of patients and minimized the bias that can occur in singlecentre studies.

The non-random choice of hospitals is a reason that the results should be interpreted with some caution, except for Iceland and Cyprus where all hospitals performing hip or knee replacement were included. The inclusion of patients and their spouses from the Nordic countries of Finland, Iceland and Sweden, which have similar family values and healthcare systems, strengthen the possibility to generalize the results of three of the papers (I, II , IV) (Polit \& Beck 2010). Even though the included hospitals from Finland and Sweden were not randomly selected it is possible to conclude, according to information on length of hospital stay, and outcome after arthroplasty in the national hip and knee registers, that the sample is representative of a larger group of patients (Puolakka et al., 2001, Sundberg et al., 2014).

Power calculations of $\mathrm{EK}_{\mathrm{hp}}$ and $\mathrm{RK}_{\mathrm{hp}}$ were carried out for the European project and the required samples for all seven countries were 220 patients per country, while no power calculation was carried out for five or three countries. As the samples in the Nordic countries ranged from 257 to 270 , comparisons between those countries should have enough statistical power.

It is possible that the use of questionnaires at the time of hospital discharge, which is often a stressful time, might affect patients' readiness to answer the questionnaires rather than their ability to understand the questions. Low internal 
missing data and the result of the pilot study indicate that patients and spouses found the questionnaires relevant and easy to understand.

One methodological consideration was whether parametric or nonparametric tests should be used. The validity of parametric tests is based on the assumption that the data are normally distributed. With large sample sizes and hundreds of observations, it is possible to use parametric tests even though the data are non-normally distributed (Altman \& Bland 1995, 2009, Ghasemi \& Zahediasl 2012). The samples in papers III and IV comprised 306 and 865 patients, and the distribution of the QoR was tested visually by using normal plots, and by significant tests (Ghasemi \& Zahediasl 2012). The distribution was negatively skewed and the scale was normalized by using a log transformation. As the results were equal when comparing the ordinary and the normalized scale the ordinary scale and parametric tests were chosen. This choice allows international comparisons of the results.

Five of the countries, those that collected data from approximately equally large groups of both hip and knee replacement patients, were included in paper III. To gain reliable, valid and comparable results for the European project, a research protocol was used. It is difficult to achieve identical use of protocols and it is possible that the protocol could have been more specific and detailed (Hawthorne et al., 2006). For example, there was no instruction in the protocol to include the same proportion of patients undergoing hip or knee replacement. To ensure valid results when comparing QoR between patients undergoing hip or knee replacement, linear regression analyses were chosen and adjustments were made for country (III).

In the dimension of pain, patients undergoing hip replacement had significantly higher QoR compared to patients undergoing knee replacement (hip: $29.0 \pm 4.3$, knee: $28.3 \pm 4.4, p=0.025$ ). The difference in the dimension of pain between patients undergoing hip or knee replacement is small, and probably has limited clinical importance. The significance level was set at $<0.05$, and the result is probably an overly sensitive significance when applied to a large sample $(\mathrm{n}=856$, hip=413, Knee=452) (Polit \& Beck 2012). Another level of statistical significance could have been chosen to avoid accepting this difference in QoR between patients undergoing hip or knee replacement.

Patients with low or high knowledge expectations were not defined; only the difference between expected and received knowledge expectations that are defined as fulfilled or unfulfilled. Fulfilment of knowledge expectations is not related to whether the expectations are low or high and there is no cut-off when expectations are low or high. 
Attrition bias occurs when a particular category of the respondents are unable or unwilling to complete the study; therefore, careful non-response analyses were carried out and reported for all papers. To avoid reporting bias, the research protocol that was established at the start of the European project was followed during the research process.

\section{Clinical implications}

The findings from this thesis show the importance of information and education obtained from nurses, and suggests a development for current patient education. Nurses should identify patients and spouses who are at risk of having unfulfilled knowledge expectations and provide them with knowledge that supports their empowering process.

Negative emotional state is an important factor for experiencing unfulfilled knowledge expectations but also lower QoR. Nurses should therefore identify patients experiencing negative emotions such as depressive state, fear, impatience, despair or hopelessness. Not only patients' but also spouses' experiences of negative emotions such as uncertainty or depressive state were associated with patients' QoR. Preoperative interventions promoting a more positive emotional state among patients and their spouses are therefore important.

Due to today's short hospital stays, spouses play an important role during the recovery process, and should therefore be seriously taken into account by healthcare professionals.

EPE in the orthopaedic context should be based on analysis of patients' and spouses' knowledge expectations and emotional state instead of routine praxis. The content of the education should be personalised and focus on all dimension of empowering knowledge, especially the financial, social, ethical and experiential dimensions. 


\section{Recommendations for further research}

During the work on this thesis, the directions for further research have been identified.

First, there is a need to develop an intervention study with the aim of finding out how EPE, with the goal of improving patients' QoR, can be provided. Participants in the intervention should have opportunities to personalise the level, content and method of the knowledge provided. A part of the intervention that might facilitate positive changes in emotional state might be internet-based cognitive behavioural therapy.

Second, it is of interest to explore the QoR between patients that have family support during the early period of recovery in their home environment, and compare it with the QoR of patients without family support in their home.

Third, to make it easier to identify patients and spouses who are at risk of having unfulfilled knowledge expectations, there is a need to develop the instruments measuring knowledge expectations $\left(\mathrm{KE}_{\mathrm{hp}}\right.$ and $\left.\mathrm{KE}_{\mathrm{so}}\right)$ into short-form versions suitable for clinical use.

Fourth, further research is needed to find out why the differences in QoR are smaller between hip and knee arthroplasty patients in this cross-cultural, multicentre study compared with earlier single-centre studies.

Finally, a new research field that was identified during the work with the thesis: To meet patients' and their spouses' personal knowledge expectations the research within this field needs to be more inter-professional. Studying EPE from the perspective of different professions would therefore be of clinical interest. 


\section{Conclusion}

Patients and their spouses had high knowledge expectations that were not fulfilled during the hospital stay. Patients' emotional state and their access to knowledge were important for their fulfilment of knowledge expectations. Patients' and spouses' emotional state also played an important role in determining the patients' QoR, and greater satisfaction with care among the patients was associated with better QoR.

These results emphasise the need to detect patients and their spouses in need of support in their preparation and recovery process. It is therefore important to assess patients' and spouses' personal knowledge expectations, and adapt to their emotional state while fulfilling them.

The results of the thesis may contribute to a development of patient education based on the patient's personal needs. This would create better conditions for patients and their spouses to take control of their situation early in the recovery process. 



\section{Sammanfattning på svenska}

Avhandlingen berör patientutbildning som stärker egenkraften i samband med planerad höft- eller knäprotesoperation. Det engelska begreppet empowerment innebär en upplevelse av makt över sitt eget liv vilken är grunden för hälsa. Det finns ingen vedertagen översättning på svenska men begreppet egenmakt brukar användas. En person som upplever egenmakt känner till sina befintliga kunskaper och vilken kunskap som saknas, har förmågan att förstå kunskap, att fatta beslut, lösa problem och utföra egenvård som främjar den egna hälsan. Egenmakt kan inte ges till någon men exempelvis sjuksköterskor kan stödja patienter och deras partner genom att ta reda på vilken kunskap de behöver för att självständigt utföra egenvård. Den teoretiska modell för patientutbildning som avhandlingen utgår från kallas 'Empowering Patient Education' och omfattar sex dimensioner av kunskap:

- fysiologisk kunskap symtom och patientens möjligheter att kontrollera upplevda problem,

- funktionell kunskap funktionell kontroll över situationen,

- erfarenhets kunskap om användning av sina tidigare erfarenheter för att klara egenvård.

- etisk kunskap $\quad$ kunskaper för att kunna känna sig unik och respekterad i vårdsituationen,

- social kunskap möjligheter att fungera i sitt sociala sammanhang,

- ekonomisk kunskap kunskaper om ekonomiska möjligheter att klara vård och behandling.

Personer som får sina kunskapsförväntningar uppfyllda i alla dessa dimensioner har förmåga att känna makt över sin situation.

De sex dimensionerna av kunskap som tillsammans kan stärka patienternas och deras partners förmåga att självständigt ta ansvar under återhämtningsperioden kallas 'empowering knowledge'. I avhandlingen beskrivs denna kunskap och det övergripande syftet var att utforska sambandet mellan 'empowering knowledge' och kvalitén på patienternas återhämtning efter planerad höft- eller knäprotesoperation. Dessutom gjordes jämförelser mellan de som genomgått de 
två typerna av protesoperationer, liksom jämförelser mellan de olika länderna som ingick i delarbetena.

Artros är en av våra vanligaste folksjukdomar och den ökar i antal. Artros ger tidigt nedsatt rörlighet och smärta vilket leder till nedsatt livskvalitet. Kirurgisk behandling innebär att den drabbade leden byts ut mot en protes. Vårdtiden på sjukhus efter höft- och knäprotesoperation har succesivt minskat från 15 dagar på 80-talet till 4-6 dagar idag vilket innebär att återhämtningen till stor del sker i det egna hemmet. Detta kan vara en utmaning för både patienter och deras partner. Det är därför viktigt att redan under sjukhusvistelsen veta vilka personer som har behov av stöd och även vilken kunskap de har behov av. Rättigheten till information och kunskap betonas även i hälso- och sjukvårdslagstiftningen.

Avhandlingen är en del av ett Europeiskt forskningsprojekt där forskare från Cypern, Finland (projektledare), Grekland, Island, Litauen, Spanien och Sverige samarbetar. Projektet fick etiskt godkännande i alla deltagande länder.

Resultaten bygger på enkätsvar från fem länder: Cypern, Finland, Grekland, Island och Sverige och består av fyra delarbeten: I, II, III, och IV. Totalt var 1187 patienter från 12 sjukhus $\mathrm{i}$ den fem länderna villiga att delta. Av dessa inkluderades 865 patienter som genomgått höft- eller knäprotesoperation från Cypern, Finland, Grekland, Island och Sverige i delarbete III. Från de nordiska länderna Finland, Island och Sverige inkluderades 320 patienter som hade genomgått höftprotesoperation i delarbete I och 290 patienter som genomgått knäprotesoperation i delarbete II. I delarbete IV inkluderades 306 partners (make, maka, sambo) och patienter som genomgått någon av de båda protesoperationerna. De patienter och partner som inkluderades i delstudierna besvarade frågeformulär före operationen och i samband med patienternas utskrivning från sjukhus.

Resultaten visade att patienter och deras partner hade höga förväntningar på kunskap som de inte fick tillgodosedda under sjukhusvistelsen. Patienterna upplevde dock att de fick fler av sina kunskapsförväntningar uppfyllda jämfört med sin partner. Förväntningarna på fysiologisk och funktionell kunskap blev bäst tillgodosedda medan kunskap om ekonomiska möjligheter att klara vård och behandling blev sämst tillgodosedda. Det fanns även brister i hur väl patienternas egna erfarenheter togs tillvara under patientutbildningen. Patienter som upplevde känslor som nedstämdhet, rädsla och otålighet upplevde att färre av deras förväntningar på kunskap blev tillgodosedda. Negativa känslor före operationen kunde även förutsäga sämre postoperativ återhämtning. Högre tillfredställelse med vården däremot förutsåg bättre postoperativ återhämtning. 
Resultatet i delstudie I visade att patienter som genomgått höftprotesoperation förväntade sig mer kunskap än vad de fick och att en känsla av nedstämdhet eller oro bidrog negativt till detta. Patienter med högre utbildningsnivå hade färre kunskapsförväntningar uppfyllda jämfört med de som hade lägre utbildning.

Delstudie II visade att även patienter som genomgått knäprotesoperation förväntade sig mer kunskap än vad de fick och att de var nöjda med vården förutom hur deras familj förbereddes inför utskrivningen. Tillgång till kunskap innebar en högre grad av uppfyllda kunskapsförväntningar. Höga förväntningar på hälsorelaterad information innebar dock att en lägre grad av förväntningarna på kunskap uppfylldes.

Resultatet i delstudie III visade att negativa känslor före operationen var relaterade till sämre återhämtning vid utskrivning från sjukhuset. De patienter som var mer nöjda med vården uppfattade att de hade bättre återhämtning än de som var missnöjda med vården. Det fanns skillnader mellan de olika protesoperationerna, exempelvis hade patienter som opererades med höftprotes bättre återhämtning avseende smärta än de som opererades med knäprotes.

Delstudie IV visade att partnerns känslomässiga tillstånd fram för allt osäkerhet och nedstämdhet hade en negativ betydelse för patienternas återhämtning. Om sjuksköterskor förklarade patientens vård och behandling för partnern hade det positiv inverkan på patientens återhämtning.

Grunden för patientutbildning är patienternas kunskap om sin egen hälsa. Om en person upplever bristfällig kunskap kan det vara svårt att planera och utföra den egenvård som behövs efter utskrivningen från sjukhuset. Det är därför viktigt att tillfredsställa patienternas behov genom att anpassa utbildningen och vården utifrån deras personliga behov. Därmed skapas bättre förutsättningar för både patienter och deras partner att ta kontroll över sin situation under återhämtningsperioden. Med dagens allt kortare vårdtider är det viktigt att patienternas partner och andra informella vårdgivare uppfattas som en resurs under återhämtningsperioden.

Avhandlingen bidrar med ökad kunskap om vilka kunskapsbehov som uppfylls under vårdtiden och vilka faktorer som påverkar återhämtningen, och kan därmed bidra till förbättrade förutsättningar för personer som genomgår höfteller knäprotesoperation. Utifrån avhandlingens resultat och i samråd med verksamheten kan resultaten bidra till utveckling av patientutbildning och vård utifrån patientens personliga behov. Därmed skapas bättre förutsättningar för både patienter och deras närstående att ta kontroll över sin situation tidigt $\mathrm{i}$ återhämtningsfasen. 



\section{Acknowledgements}

An eventful and interesting journey has now come to an end. There has been a lot of work and I would never have been able to finish this without the friendly assistance and the contributions of many old and new friends.

I would therefore like to express my great gratitude to:

First, all the patients and spouses who took your time to answer questionnaires. Without you this thesis would not have existed.

Margareta Bachrach-Lindström, Associate Professor and main supervisor, for your encouragement, friendship and great support, and for sharing both "good and bad" experiences of life.

Sanna Salanterä, Professor and supervisor, for sharing your wisdom and encouragements.

The leaders of the European research project; Adjunct professor Kirsi Valkeapää, and Professor Helena Leino-Kilpi for your warm welcome to the project and encouragements, and also the Department of Nursing Science at University of Turku for offering the postgraduate course on Empowering Patient Education which was of great value to me during the entire process.

Ingbritt Morell, Peter Rockborn, Anna Claesson Sonsong and Håkan Löfgren for friendly support during the data collection period, and also the numerous other people that participated in patient recruitment and data collection in all participating countries. 
The co-authors: Docent Andreas Charalambous, Associated Professor Natalja Istomina, Professor Helena Leino-Kilpi, Professor Arun Sigurdardottir, Professor Panayota Sourtzi, Adjunct professor Kirsi Valkeapää, PhD Adelaida Zabalegui, for friendly cooperation and valuable comments on the manuscripts, and particularly PhD-student Brynja Ingadottir for your friendship, cooperation and support.

Elisabeth Wilhelm and Jouko Katajisto for the valuable statistical support.

All my colleagues at the division of Nursing Science, and the division of Occupational Therapy, the department of Social and Welfare Studies, Linköping University, for your support.

The PhD-students at the divisions of Nursing Science, and the division of Occupational Therapy at the Faculty of Medicine and Health Sciences, for your support and help, for challenging questions and discussions during our seminars, but also lots of "After Work discussions", particularly Jeanette Eckerblad who supported me in different ways during the whole journey.

My sister in law, Margit Johansson for valuable help with language revision.

Finally, above all, my beloved family; Mats, Hanna and Johan, Erik and Jessica.

\section{Thank you all!}

Norrköping in Mars 2016

Åsa Johansson Stark 


\section{References}

Cultural map, 2010-2014. Available at: http://www.worldvaluessurvey.org/WVSContents.jsp (accessed 201505 16).

Act 74/1997, Act on Patients' Rights, Iceland. Available at: http://www.althingi.is/lagas/138b/1997074.html (accessed 2015-05-17).

Act 785/1992, About Patients' Rights, Finland. Available at: http://www.finlex.fi/en/laki/kaannokset/1992/en19920785.pdf (accessed 201505-17).

Act 1982:763, Health and Medical Services, Sweden. Available at: http://www.notisum.se/rnp/sls/lag/19820763.HTM (accessed 2015-05-17).

Act GR-2071/92, \& 2619/98, Ministry of Health and Social Solidarity, Greece.

Allvin R, Berg K, Idvall E \& Nilsson U (2007): Postoperative recovery: a concept analysis. Journal of Advanced Nursing 57, 552-558.

Allvin R, Ehnfors M, Rawal N \& Idvall E (2008): Experiences of the postoperative recovery process: an interview study. Open Nursing Journal 2, 1-7.

Altman DG \& Bland JM (1995): Statistics notes: the normal distribution. BMJ 310, 298.

Altman DG \& Bland JM (2009): Parametric v non-parametric methods for data analysis. BMJ 338, a3167.

Anastase DM, Cionac Florescu S, Munteanu AM, Ursu T \& Stoica CI (2014): Analgesic techniques in hip and knee arthroplasty: from the daily practice to evidence-based medicine. Anesthesiology research and practice 2014, 569319.

Aujoulat I, Marcolongo R, Bonadiman L \& Deccache A (2008): Reconsidering patient empowerment in chronic illness: A critique of models of self-efficacy and bodily control. Social Science \& Medicine 66, 1228-1239.

Baucom DH, Porter LS, Kirby JS \& Hudepohl J (2012): Couple-Based Interventions for Medical Problems. Behavior Therapy 43, 61-76.

Berg K, Arestedt K \& Kjellgren K (2013): Postoperative recovery from the perspective of day surgery patients: a phenomenographic study. International journal of nursing studies 50, 1630-1638.

Berggren H, Eklund K \& Trädgårdh L (2011) The Nordic Way, Shared norms for the new reality, World Economic Forum, Davos. 
Bergh AL, Karlsson J, Persson E \& Friberg F (2012): Registered nurses' perceptions of conditions for patient education - focusing on organisational, environmental and professional cooperation aspects. Journal of nursing management 20, 758-770.

Bowyer A, Jakobsson J, Ljungqvist O \& Royse C (2014): A review of the scope and measurement of postoperative quality of recovery. Anaesthesia 69, 1266-1278.

Bradbury-Jones C, Sambrook S \& Irvine F (2008): Power and empowerment in nursing: a fourth theoretical approach. Journal of Advanced Nursing 62, 258-266.

Bragstad LK, Kirkevold M, Hofoss D \& Foss C (2014): Informal caregivers' participation when older adults in Norway are discharged from the hospital. Health and Social Care in the Community 22, 155-168.

Browne JP, Bastaki H \& Dawson J (2013): What is the optimal time point to assess patient-reported recovery after hip and knee replacement? a systematic review and analysis of routinely reported outcome data from the English patientreported outcome measures programme. Health and Quality of Life Outcomes 11.

Caracciolo B \& Giaquinto S (2005): Self-perceived distress and self-perceived functional recovery after recent total hip and knee arthroplasty. Archives of Gerontology and Geriatrics 41, 177-181.

Charalambous A, Efstathiou G, Adamakidou T \& Tsangari H (2014): Adult cancer patients satisfaction of nursing care: a cross-national evaluation of two Southeastern European countries. The International Journal of Health Planning and Management 29, e329-e346.

Choi JK, Geller JA, Yoon RS, Wang W \& Macaulay W (2012): Comparison of Total Hip and Knee Arthroplasty Cohorts and Short-Term Outcomes From a SingleCenter Joint Registry. The Journal of Arthroplasty 27, 837-841.

de Beer J, Petruccelli D, Adili A, Piccirillo L, Wismer D \& Winemaker M (2012): Patient perspective survey of total hip vs total knee arthroplasty surgery. The Journal of Arthroplasty 27, 865-869 e861-865.

Demir SG \& Erdil F (2013): Effectiveness of home monitoring according to the Model of Living in hip replacement surgery patients. Journal of Clinical Nursing 22, 1226-1241.

Duivenvoorden T, Vissers MM, Verhaar JA, Busschbach JJ, Gosens T, Bloem RM, Bierma-Zeinstra SM \& Reijman M (2013): Anxiety and depressive symptoms before and after total hip and knee arthroplasty: a prospective multicentre study. Osteoarthritis Cartilage 21, 1834-1840.

Economou C (2010) Greece: Health system review. Health Systems in Transition, pp. 1180. 
EEPO (2009) Empowering surgical orthopaedic patients through education. University of Turku, Department of Nursing Science, Turku. Available at: http://www.utu.fi/en/units/med/units/hoitotiede/research/projects/epe/research/P ages/eepo.aspx (accessed 07-07 2015).

EGGE (2012) EU Expert Group on Gender and Employment (EGGE), Long-Term Care for the elderly -Provisions and providers in 33 European countries. European Union. Available at: http://ec.europa.eu/justice/genderequality/files/elderly_care_en.pdf (accessed 20150723 ).

Eloranta S, Katajisto J \& Leino-Kilpi H (2015): Orthopaedic patient education practice. International Journal of Orthopaedic and Trauma Nursing. (in press)

EPF (2013) European Patients Forum (EPF) Strategic plan 2014-2020.

EU (2014) EU summit on chronic diseases. European Commision, Health and consumers directorate-general, Public health. Available at: http://ec.europa.eu/health/major_chronic_diseases/docs/ev_20140403_mi_en.pdf

Fransen M, McConnell S, Harmer AR, Van der Esch M, Simic M \& Bennell KL (2015): Exercise for osteoarthritis of the knee: a Cochrane systematic review. British Journal of Sports Medicine.

Fraval A, Chandrananth J, Chong YM, Tran P \& Coventry LS (2015): Internet based patient education improves informed consent for elective orthopaedic surgery: a randomized controlled trial. BMC Musculoskeletal Disorders 16, 14.

Friberg F, Granum V \& Bergh AL (2012): Nurses' patient-education work: conditional factors - an integrative review. Journal of nursing management 20, 170-186.

Fumagalli LP, Radaelli G, Lettieri E, Bertele' P \& Masella C (2015): Patient Empowerment and its neighbours: Clarifying the boundaries and their mutual relationships. Health Policy 119, 384-394.

Gandhi R, Zywiel MG, Mahomed NN \& Perruccio AV (2015): Depression and the Overall Burden of Painful Joints: An Examination among Individuals Undergoing Hip and Knee Replacement for Osteoarthritis. Arthritis 2015, 327161 .

Ghasemi A \& Zahediasl S (2012): Normality tests for statistical analysis: a guide for non-statisticians. International Journal of Endocrinology and Metabolism 10, 486-489.

Gibson CH (1991): A Concept Analysis of Empowerment. Journal of Advanced Nursing 16, 354-361.

Gooberman-Hill R, French M, Dieppe P \& Hawker G (2009): Expressing pain and fatigue: a new method of analysis to explore differences in osteoarthritis experience. Arthritis \& Rheumatism 61, 353-360. 
Gornall BF, Myles PS, Smith CL, Burke JA, Leslie K, Pereira MJ, Bost JE, Kluivers KB, Nilsson UG, Tanaka Y \& Forbes A (2013): Measurement of quality of recovery using the QoR-40: a quantitative systematic review. British Journal of Anaesthesia.

Grant S, St John W \& Patterson E (2009): Recovery From Total Hip Replacement Surgery: "It's Not Just Physical". Qualitative Health Research 19, 1612-1620.

Grover M \& Haire K (2004): Discharge after ambulatory surgery. Current Anaesthesia \& Critical Care 15, 331-335.

Gustafsson B, Ekman S, Ponzer S \& Heikkilä K (2010): The hip and knee replacement operation: an extensive life event. Scandinavian Journal of Caring Sciences 24, 663-670.

Hamel MB, Toth M, Legedza A \& Rosen MP (2008): Joint replacement surgery in elderly patients with severe osteoarthritis of the hip or knee - Decision making, postoperative recovery, and clinical outcomes. Archives of Internal Medicine 168, 1430-1440.

Heikkinen K, Leino-Kilpi H, Hiltunen A, Johansson K, Kaljonen A, Rankinen S, Virtanen H \& SalanterÄ S (2007): Ambulatory orthopaedic surgery patients' knowledge expectations and perceptions of received knowledge. Journal of Advanced Nursing 60, 270-278.

Heikkinen K, Leino-Kilpi H \& Salantera S (2012a): Ambulatory orthopaedic surgery patients' knowledge with internet-based education. Methods of information in medicine 51, 295-300.

Heikkinen K, Salanterä S, Leppanen T, Vahlberg T \& Leino-Kilpi H (2012b): Ambulatory orthopaedic surgery patients' emotions when using different patient education methods. Journal of perioperative practice 22, 226-231.

Hoving C, Visser A, Mullen PD \& van den Borne B (2010): A history of patient education by health professionals in Europe and North America: From authority to shared decision making education. Patient Education and Counseling 78, 275-281.

ICN (2012) The ICN code of ethics for nurses. International Council of Nurses. Available at: http://www.icn.ch/images/stories/documents/about/icncode_english.pdf (accessed 2015-11-29).

Johansson L, Long H \& Parker MG (2011): Informal caregiving for elders in Sweden: an analysis of current policy developments. Journal Of Aging \& Social Policy 23, 335-353.

Kagan I \& Bar-Tal Y (2008): The effect of preoperative uncertainty and anxiety on short-term recovery after elective arthroplasty. Journal of Clinical Nursing 17, 576-583. 
Kearney M, Jennrich MK, Lyons S, Robinson R \& Berger B (2011): Effects of Preoperative Education on Patient Outcomes After Joint Replacement Surgery. Orthopaedic Nursing 30, 391-396.

Kennedy S, Hardiker N \& Staniland K (2015): Empowerment an essential ingredient in the clinical environment: A review of the literature. Nurse education today $\mathbf{3 5}$, 487-492.

Khan CM, Iida M, Stephens MA, Fekete EM, Druley JA \& Greene KA (2009): Spousal support following knee surgery: roles of self-efficacy and perceived emotional responsiveness. Rehabilitation Psychology 54, 28-32.

*Klemetti S, Leino-Kilpi H, Cabrera E, Copanitsanou P, Ingadottir B, Istomina N, Katajisto J, Papastavrou E, Unosson M \& Valkeapää K (2014): Difference Between Received and Expected Knowledge of Patients Undergoing Knee or Hip Replacement in Seven European Countries. Clinical nursing research.

*Koekenbier K, Leino-Kilpi H, Cabrera E, Istomina N, Johansson Stark A, Katajisto J, Lemonidou C, Papastavrou E, Salanterä S, Sigurdardottir A, Valkeapää K \& Eloranta S (2015): Empowering knowledge and its connection to health-related quality of life: a cross-cultural study. Applied Nursing Research.

Krantz DS, Baum A \& Wideman MV (1980): Assessment of preferences for selftreatment and information in health care. Journal of Personality and Social Psychology 39, 977-990.

Kuokkanen L \& Leino-Kilpi H (2000): Power and empowerment in nursing: three theoretical approaches. Journal of Advanced Nursing 31, 235-241.

Laird EA, McCance T, McCormack B \& Gribben B (2015): Patients' experiences of inhospital care when nursing staff were engaged in a practice development programme to promote person-centredness: A narrative analysis study. International journal of nursing studies 52, 1454-1462.

Lamura G, Mnich E, Nolan M, Wojszel B, Krevers B, Mestheneos L, Dohner H \& Group E (2008): Family carers' experiences using support services in Europe: empirical evidence from the EUROFAMCARE study. Gerontologist 48, 752771.

Leino-Kilpi H, Grondahl W, Pekonen A, Katajisto J, Suhonen R, Valkeapaa K, Virtanen H \& Salantera S (2014): Knowledge received by hospital patients-a factor connected with the patient-centred quality of nursing care. International Journal of Nursing Practice.

Leino-Kilpi H, Heikkinen K, Hiltunen A, Johansson K, Kaljonen A, Virtanen H \& Salantera S (2009): Preference for information and behavioral control among adult ambulatory surgical patients. Applied nursing research : ANR 22, 101-106. 
Leino-Kilpi H, Johansson K, Heikkinen K, Kaljonen A, Virtanen H \& Salantera S (2005a): Patient education and health-related quality of life: surgical hospital patients as a case in point. Journal of Nursing Care Quality 20, 307-316; quiz 317-308.

Leino-Kilpi H, Johansson K, Heikkinen K, Kaljonen A, Virtanen H \& Salanterä S (2005b): Patient education and health-related quality of care. Journal of Nursing Care Quality 20, 307-316.

Leino-Kilpi H, Luoto E \& Katajisto J (1998): Elements of empowerment and MS patients. Journal of Neuroscience Nursing 30, 116-123.

Leino-Kilpi H, Maenpaa I \& Katajisto J (1999): Nursing study of the significance of reumatoid arthritis as perceived by patients using the concept of empowerment. Journal of Orthopaedic Nursing 3, 138-145.

Leino-Kilpi H \& Vuorenheimo J (1994): The patient's perspective on nursing quality: developing a framework for evaluation. International Journal for Quality in Health Care 6, 85-95.

Lewis MA, McBride CM, Pollak KI, Puleo E, Butterfield RM \& Emmons KM (2006): Understanding health behavior change among couples: an interdependence and communal coping approach. Social Science \& Medicine 62, 1369-1380.

Lohmander LS, Engesaeter LB, Herberts P, Ingvarsson T, Lucht U \& Puolakka TJ (2006): Standardized incidence rates of total hip replacement for primary hip osteoarthritis in the 5 Nordic countries: similarities and differences. Acta orthopaedica 77, 733-740.

Louw A, Diener I, Butler DS \& Puentedura EJ (2013): Preoperative education addressing postoperative pain in total joint arthroplasty: review of content and educational delivery methods. Physiotherapy Theory and Practice 29, 175-194.

Macpherson R, Pesola F, Leamy M, Bird V, Le Boutillier C, Williams J \& Slade M (2015): The relationship between clinical and recovery dimensions of outcome in mental health. Schizophrenia Research.

McCormack B, Roberts T, Meyer J, Morgan D \& Boscart V (2012): Appreciating the 'person' in long-term care. International journal of older people nursing 7, 284294.

Meyler D, Stimpson JP \& Peek MK (2007): Health concordance within couples: A systematic review. Social Science \& Medicine 64, 2297-2310.

Morgan S \& Yoder LH (2012): A concept analysis of person-centered care. Journal of holistic nursing 30, 6-15. 
Murphy S, Conway C, McGrath NB, O'Leary B, O'Sullivan MP \& O'Sullivan D (2011): An intervention study exploring the effects of providing older adult hip fracture patients with an information booklet in the early postoperative period. Journal of Clinical Nursing 20, 3404-3413.

Myles PS (2009) Procedures Manual and guide to Measurement of Quality of Recovery after Surgery and Anaesthesia using the QoR-40, version 3.0. Dept of Anaestesia $\&$ Perioperative Medicine, Alfred Hospital, Melbourne, Australia.

Myles PS, Weitkamp B, Jones K, Melick J \& Hensen S (2000): Validity and reliability of a postoperative quality of recovery score: the QoR-40. British Journal of Anaesthesia 84, 11-15.

Mäkelä KT, Matilainen M, Pulkkinen P, Fenstad AM, Havelin LI, Engesaeter L, Furnes O, Overgaard S, Pedersen AB, Karrholm J, Malchau H, Garellick G, Ranstam J \& Eskelinen A (2014): Countrywise results of total hip replacement. An analysis of 438,733 hips based on the Nordic Arthroplasty Register Association database. Acta orthopaedica 85, 107-116.

O'Brien S, Bennett D, Doran E \& Beverland DE (2009): Comparison of hip and knee arthroplasty outcomes at early and intermediate follow-up. Orthopedics 32, 168.

OECD (2014) Health at a Glance: Europe 2014, OECD Publishing. Available at: http://dx.doi.org/10.1787/health_glance_eur-2014-en

Olsson LE, Karlsson J, Berg U, Karrholm J \& Hansson E (2014): Person-centred care compared with standardized care for patients undergoing total hip arthroplasty-a quasi-experimental study. Journal of Orthopaedic Surgery and Research 9, 95.

Oudshoorn A (2005): Power and empowerment: critical concepts in the nurse-client relationship. Contemporary nurse 20, 57-66.

Parida S \& Badhe AS (2014): Comparison of cognitive, ambulatory, and psychomotor recovery profiles after day care anesthesia with propofol and sevoflurane. Journal of Anesthesia 28, 833-838.

Perry MA, Hudson HS, Meys S, Norrie O, Ralph T \& Warner S (2012): Older adults' experiences regarding discharge from hospital following orthopaedic intervention: A metasynthesis. Disability \& Rehabilitation 34, 267-278.

Pinto PR, McIntyre T, Ferrero R, Almeida A \& Araujo-Soares V (2013): Predictors of acute postsurgical pain and anxiety following primary total hip and knee arthroplasty. Journal of Pain 14, 502-515.

Polit DF \& Beck CT (2010): Generalization in quantitative and qualitative research: myths and strategies. International journal of nursing studies 47, 1451-1458.

Polit DF \& Beck CT (2012) Nursing research : generating and assessing evidence for nursing practice, Denise F. Polit, Cheryl Tatano Beck. Philadelphia : Wolters Kluwer Health, Lippincott Williams \& Wilkins, cop. 2012, 9.ed. 
Rabin R \& de Charro F (2001): EQ-5D: a measure of health status from the EuroQol Group. Annals of Medicine 33, 337-343.

Rankinen S, Salanterä S, Heikkinen K, Johansson K, Kaljonen A, Virtanen H \& LeinoKilpi H (2007): Expectations and received knowledge by surgical patients. International Journal for Quality in Health Care 19, 113-119.

Rantanen M, Kallio T, Johansson K, Salantera S, Virtanen H \& Leino-Kilpi H (2008): Knowledge expectations of patients on dialysis treatment. Nephrology nursing journal 35, 249-255; quiz 256.

Rappaport J (1984): Studies in empowerment: Introduction to the issue. Prevention in Human Services 3, 1-7.

Reay PA, Horner B \& Duggan R (2015): The patient's experience of early discharge following total hip replacement. International Journal of Orthopaedic and Trauma Nursing 19, 131-139.

Ryhanen AM, Rankinen S, Siekkinen M, Saarinen M, Korvenranta H \& Leino-Kilpi H (2012): The impact of an empowering Internet-based Breast Cancer Patient Pathway programme on breast cancer patients' knowledge: a randomised control trial. Patient Education and Counseling 88, 224-231.

Sapountzi-Krepia D, Raftopoulos V, Psychogiou M, Sakellari E, Toris A, Vrettos A \& Arsenos P (2008): Dimensions of informal care in Greece: the family's contribution to the care of patients hospitalized in an oncology hospital. Journal of Clinical Nursing 17, 1287-1294.

Searle JR (1999): The future of philosophy. Philosophical Transactions of the Royal Society of London. Series B, Biological Sciences 354, 2069-2080.

*Sigurdardottir AK, Leino-Kilpi H, Charalambous A, Katajisto J, Johansson Stark A, Sourtzi P, Zabalegui A \& Valkeapää K (2015): Fulfilment of knowledge expectations among family members of patients undergoing arthroplasty: a European perspective. Scandinavian Journal of Caring Sciences.

Slade M \& Longden E (2015): Empirical evidence about recovery and mental health. BMC Psychiatry 15, 285.

Soever LJ, Mackay C, Saryeddine T, Davis AM, Flannery JF, Jaglal SB, Levy C \& Mahomed N (2010): Educational needs of patients undergoing total joint arthroplasty. Physiotherapy Canada 62, 206-214.

Stephens MAP, Fekete EM, Franks MM, Rook KS, Druley JA \& Greene K (2009): Spouses' use of pressure and persuasion to promote osteoarthritis patients' medical adherence after orthopedic surgery. Health Psychology 28, 48-55. 
Suhonen R, Papastavrou E, Efstathiou G, Tsangari H, Jarosova D, Leino-Kilpi H, Patiraki E, Karlou C, Balogh Z \& Merkouris A (2012): Patient satisfaction as an outcome of individualised nursing care. Scandinavian Journal of Caring Sciences 26, 372-380.

Sundberg M, Lidgren L, W-Dahl A \& Robertsson O (2014): The Swedish Knee Arthroplasty Register.

Svedberg P, Ivarsson B, Nilsson U, Roxberg A, Baigi A, Brunt D, Brannström M, Fridlund B, Persson S, Rask M \& Alm-Roijer C (2012): Psychometric evaluation of a Swedish version of Krantz Health Opinion Survey. Open Journal of Nursing 2, 181-187.

Tay Swee Cheng R, Klainin-Yobas P, Hegney D \& Mackey S (2015): Factors relating to perioperative experience of older persons undergoing joint replacement surgery: an integrative literature review. Disability and Rehabilitation 37, 9-24.

Theodorou MC, C. Petrou, C. Cylus, J. (2012) Cyprus: Health system review. Health Systems in Transition., pp. 1-128.

Ulin K, Olsson LE, Wolf A \& Ekman I (2015): Person-centred care - An approach that improves the discharge process. European Journal of Cardiovascular Nursing.

Vaartio-Rajalin H, Leino-Kilpi H, Iire L, Lehtonen K \& Minn H (2015): Oncologic Patients' Knowledge Expectations and Cognitive Capacities During Illness Trajectory: Analysis of Critical Moments and Factors. Holistic nursing practice. 29, 232-244.

Vaartio-Rajalin H, Leino-Kilpi H, Zabalegui A, Valverde M, Mantecon A \& Puukka P (2014): Cancer patients' expectations regarding empowering knowledge and nurse advocacy in Finland and Spain. Clinical Nursing Studies 2, 8-21.

*Valkeapää K, Klemetti S, Cabrera E, Cano S, Charalambous A, Copanitsanou P, Ingadottir B, Istomina N, Johansson Stark A, Katajisto J, Lemonidou C, Papastavrou E, Sigurdardottir AK, Sourtzi P, Unosson M, Zabalegui A \& LeinoKilpi H (2014): Knowledge expectations of surgical orthopaedic patients: a European survey. International Journal of Nursing Practice 20, 597-607.

van den Akker-Scheek I, Zijlstra W, Groothoff JW, van Horn JR, Bulstra SK \& Stevens M (2007): Groningen orthopaedic exit strategy: Validation of a support program after total hip or knee arthroplasty. Patient Education and Counseling 65, 171179.

Vandekinderen C, Roets G, Roose R \& Van Hove G (2012): Rediscovering Recovery: Reconceptualizing Underlying Assumptions of Citizenship and Interrelated Notions of Care and Support. Scientific World Journal. 
Whitley R (2014): Introducing recovery. Canadian journal of psychiatry 59, 233-235.

WHO (2012) Chronic diseases and health promotion: Chronic rheumatic conditions. World Health Organisation. Available at: http://www.who.int/chp/topics/rheumatic/en/ (accessed 10-06 2013).

WHO/Europe (2015) Health system reviews. Health Systems in Transition. the European Observatory on Health Systems and Policies Available at: http://www.euro.who.int/en/about-us/partners/observatory/publications/healthsystem-reviews-hits (accessed 09-04 2015).

Virtanen H, Leino-Kilpi H \& Salantera S (2007): Empowering discourse in patient education. Patient Education and Counseling 66, 140-146.

Visser A, Deccache A \& Bensing J (2001): Patient education in Europe: united differences. Patient Education and Counseling 44, 1-5.

WMA (2013) Declaration of Helsinki - Ethical Principles for Medical Research Involving Human Subjects. World Medical Association (WMA). Available at: http://www.wma.net/en/30publications/10policies/b3/index.html2015-05-17).

Yoon RS, Nellans KW, Geller JA, Kim AD, Jacobs MR \& Macaulay W (2010): Patient Education Before Hip or Knee Arthroplasty Lowers Length of Stay. Journal of Arthroplasty 25, 547-551.

Zweers D, de Graaf E \& Teunissen SCCM (2015): Non-pharmacological nurse-led interventions to manage anxiety in patients with advanced cancer: A systematic literature review. International journal of nursing studies.

Publications from the European project 'Empowering Surgical Orthopaedic Patients though Education' are marked with an asterisk (*). 


\section{Papers}

The articles associated with this thesis have been removed for copyright reasons. For more details about these see:

http://urn.kb.se/resolve?urn=urn:nbn:se:liu:diva-125237 